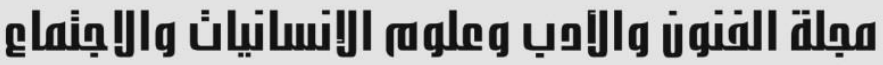

\section{فرق الإباضية وأصولهم العقدية}

حسن سعدي محمد

وزارة الأوقافت والثؤون الدينية ـ اربيل ـ اقليم كردستان العراق malik9dilshad@gmail.com الإيميل

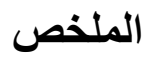

الفرق الإسلامية متعددة ومتفرقة، وذللك يرجع إلى اسباب عدة؛ منها ماهي داخلية ومنها ماهي خارجية.

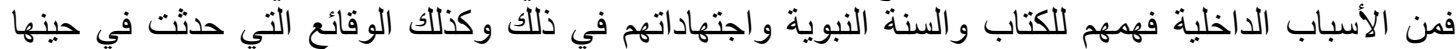
خاصة الخلافات السياسية بين الفرق الإسلامية. ومن الأسباب الخارجية احتكالك المسلمين بالحضار الات و الثقافات الأخرى وكذا حركة الترجمة التي كانت نقطة تاريخية في التاريخ الأسلامي. ولكل فرقة من الفرق الإسلامية تاريخ خاص بها، من الإن نشأتها وتطور ها وآر ائها العقدية و الفكرية وكذا الفقهية. هذا البحث يتناول فرقة من الفرق الإسلامية التي لها مذهبها العقدي الخاص بها وآرآرائها التها الكلامية التي تتميز بها

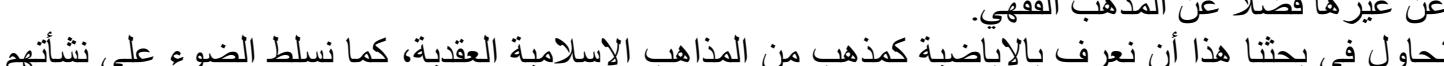

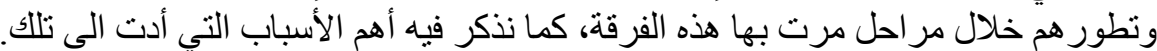

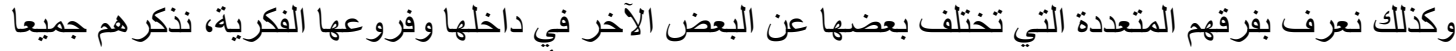

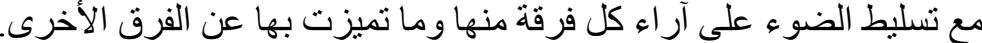

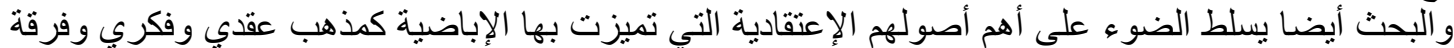

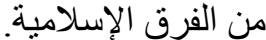
فنحاول ذكر أصولها بصورة عامة، تللك الأصول التي تشترك فيه الفرق الإباضية المتعددة فضلا عن كونهم فرقا مختلفة ولها آر اء مختلفة. 


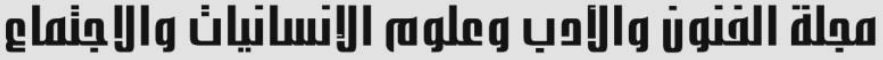

\section{Ibadi Teams and Their Contractual Origin}

\author{
Hasan Saadi Mohammed \\ Ministry of Endowments and Religious Affairs - Erbil - Kurdistan Regional - Iraq \\ Email: malik9dilshad@gmail.com
}

\begin{abstract}
Islamic teams are multiple and sporadic, due to several reasons, including what are internal and what are external.

Among the internal reasons are their understanding of the book and the Sunnah of the Prophet and their jurisprudence in this, as well as the facts that occurred at the time, especially political differences between the Islamic sects.

External causes include the contact of Muslims with other civilizations and cultures, as well as the translation movement, which was a historical point in Islamic history.

Each Islamic group has its own history, its origins and development and its contractual and intellectual views as well as jurisprudence.

This research deals with a group of Islamic groups that have their own doctrinal doctrine and verbal opinions that distinguish them from others, as well as juristic doctrine.

In our research, we try to define the Ibadis as a doctrinal Islamic doctrine, as we shed light on their origin and development during the stages that this group went through, as we mention in it the most important reasons that led to these.

We also know their various teams, which differ from each other within it and its intellectual branches. We remind them all with highlighting the opinions of each of them, and what distinguished them from the others.

The research also sheds light on the most important of their belief beliefs that distinguished Ibaadis as a doctrinal and intellectual doctrine and a group of Islamic groups.
\end{abstract}

We try to mention their origins in general, those assets that are shared by multiple

Ibadi groups as well as being different teams and have different opinions

Keywords: Islamic sects, Ibadhi. 


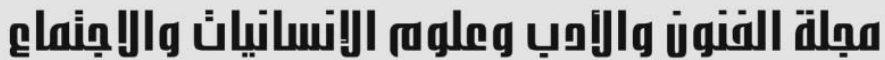

Journal of Arts, Literature, Humanities and Social Sciences

\section{www.jalhss.com}

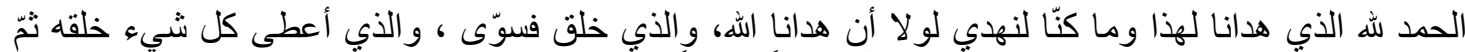

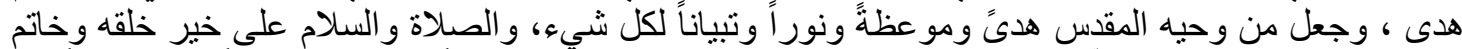

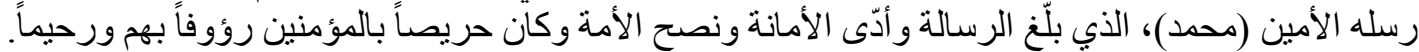

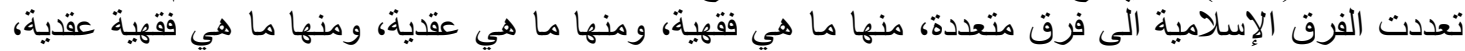

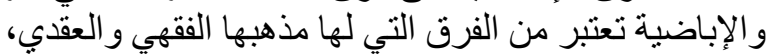

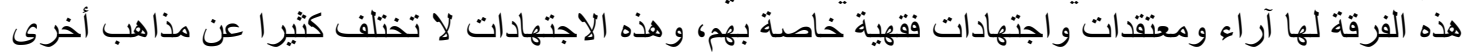

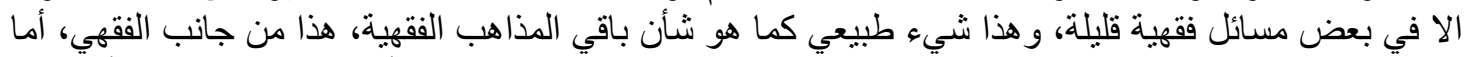

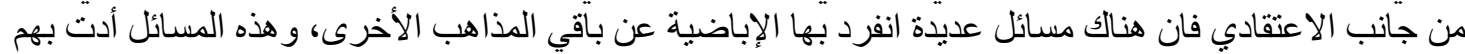

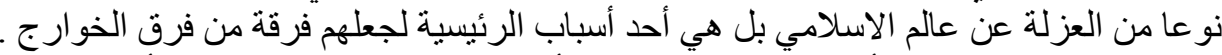

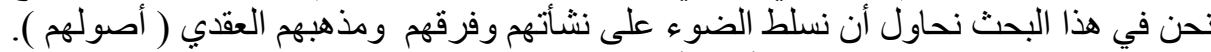

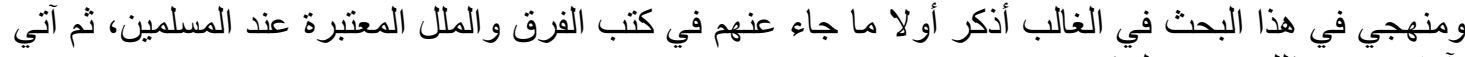
بآر اءهم عن ذلك من خلا هلال كتبهم. أهمية هذا البحث تكمن في التعرف بهذا المذهب وآرائهم من خلال كتبهم على قدر الإمكان.

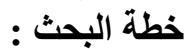

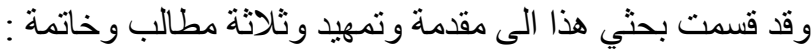

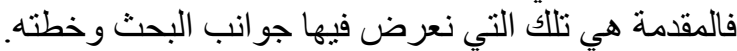

و التمهيد ينتاول التعريف بالاباضية. و والمطلب الاول : نشأة مذهب الاباضية. و والمطلب الثاني : فرق الاباضية و وآر اهم. و المطلب الثالث: أصول مذهب الإباضية الاعتقادية آلادية.

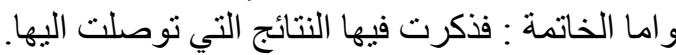




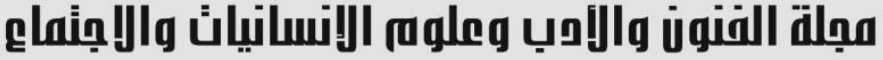

\section{www.jalhss.com}

\section{التمهيد \\ التعريف بالإباضية}

الحديث عن الإباضية يدفعنا للحديث قليلا عن فرقة الأم وهي الخوارج، وذللك لأن كتب الفرق و الملإيل جعلهم فرقة الإنة

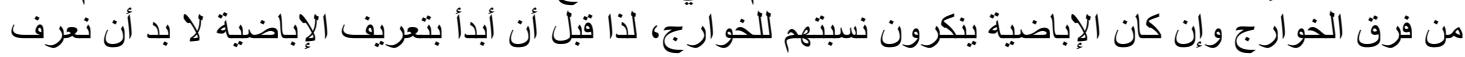

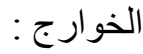

الخوارج : لغة : لفظة عربية ومفردها ( خارج ) فيقال : خرج من مكان ما ووجد لامر ما مخرجا أي : مخلصا

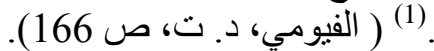

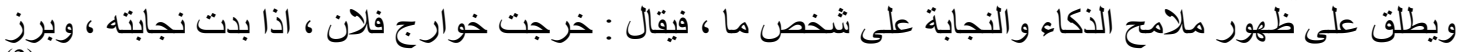

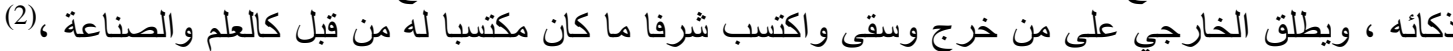

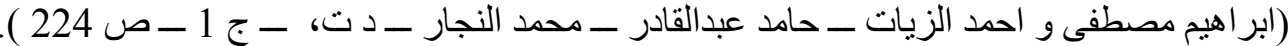

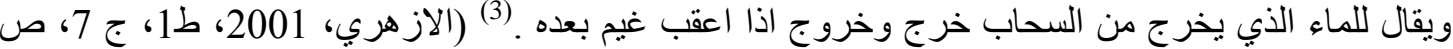

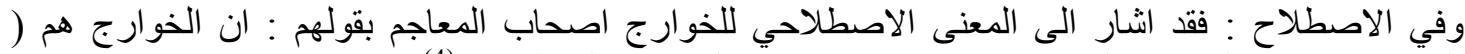

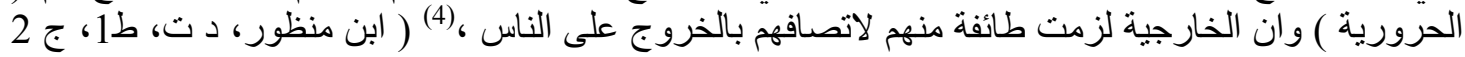

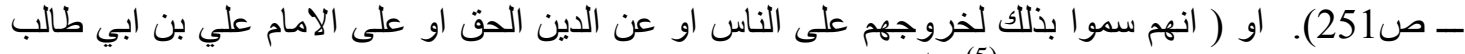

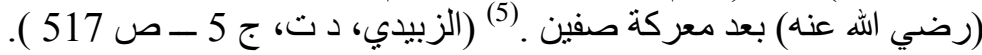

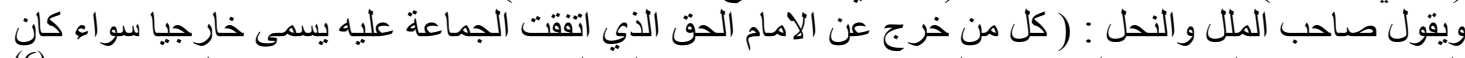

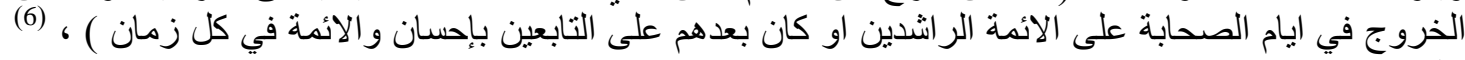

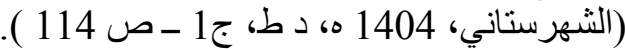

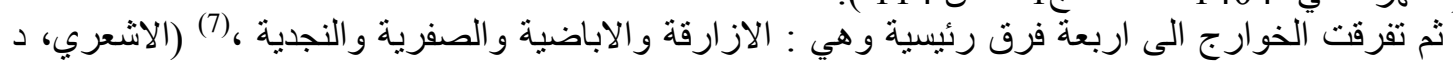

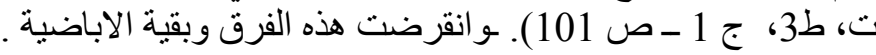

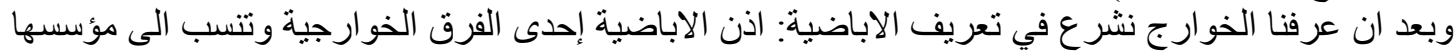

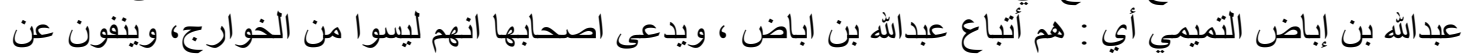

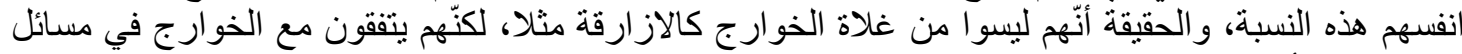

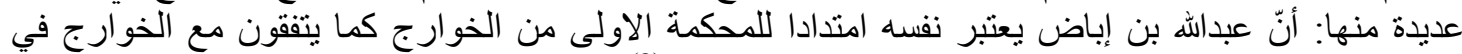

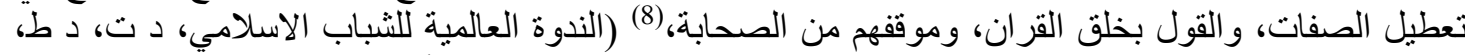

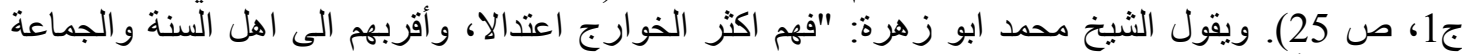

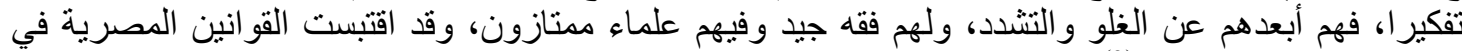

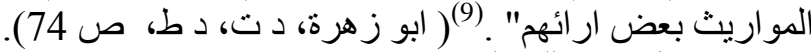

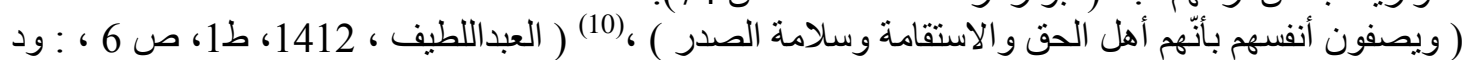

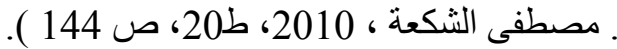

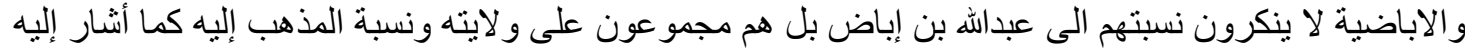

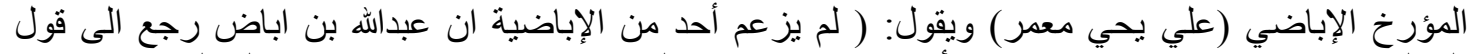

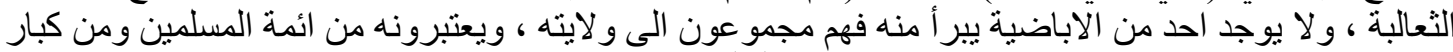

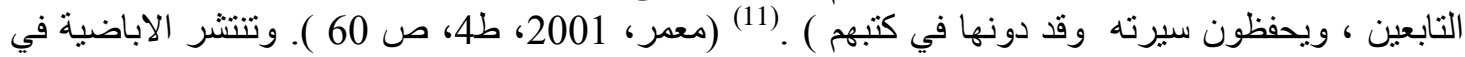

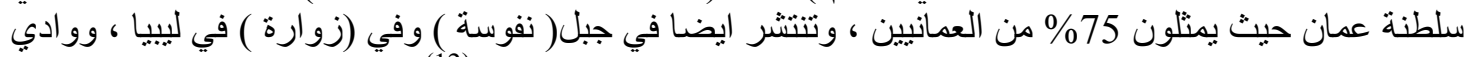

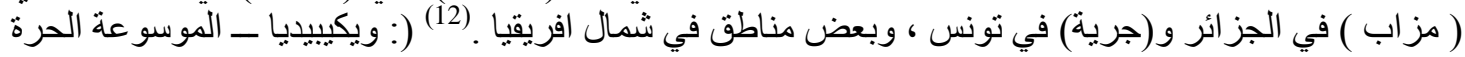




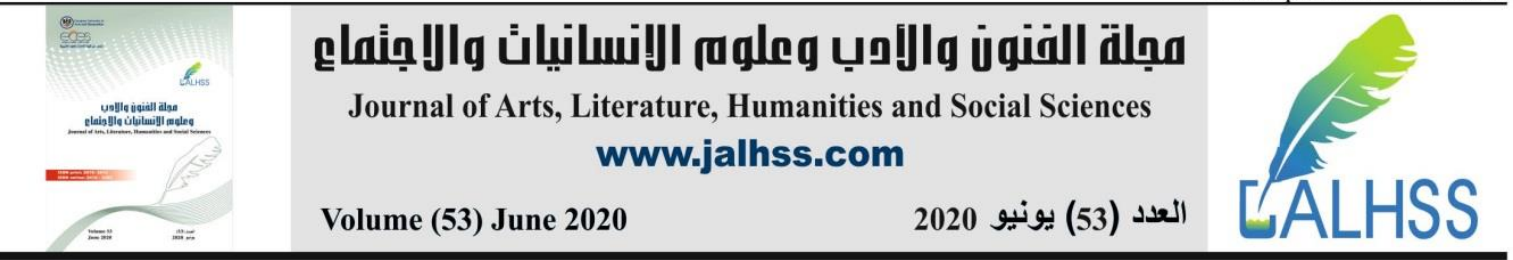

\section{المطلب الأول \\ نشأة مذهب الإباضية}

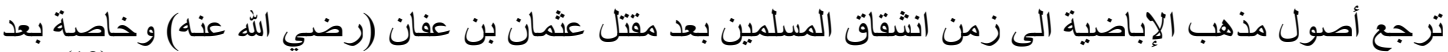

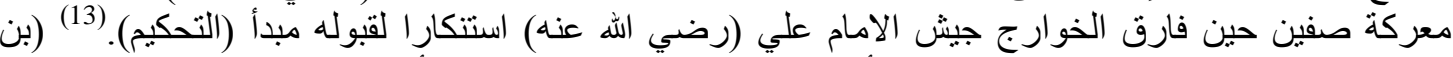

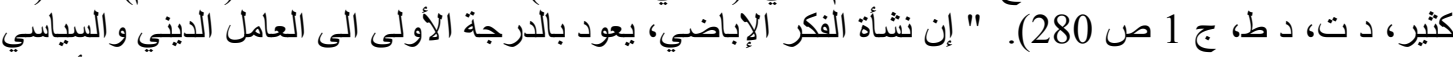

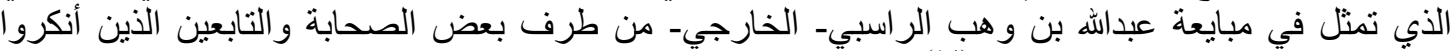

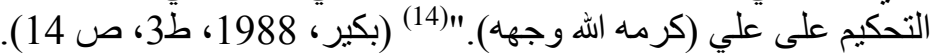

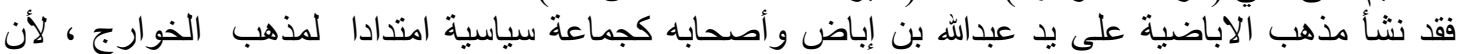

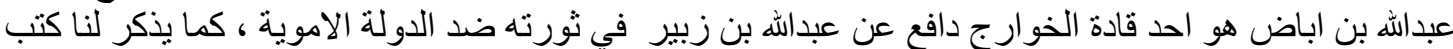

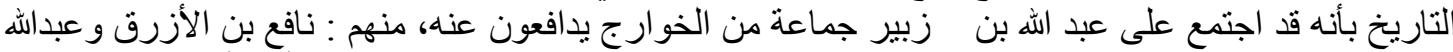

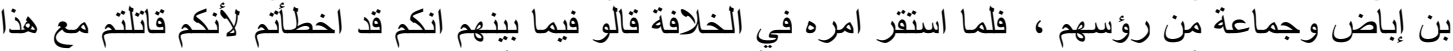

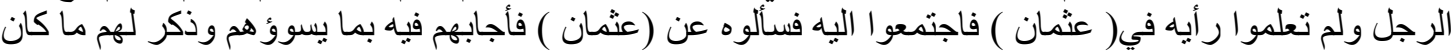

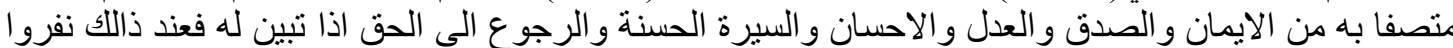

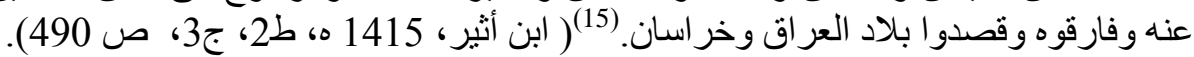

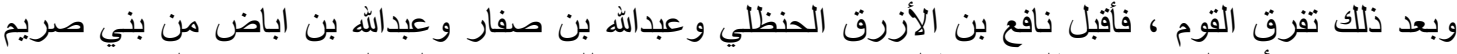

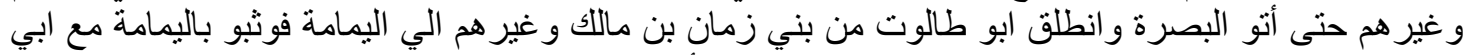

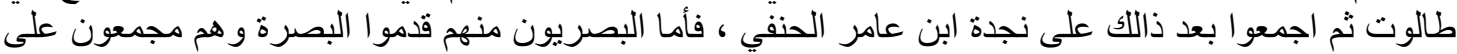

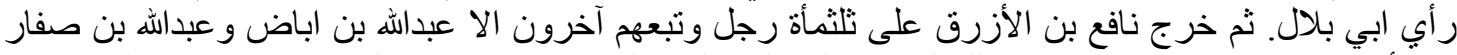

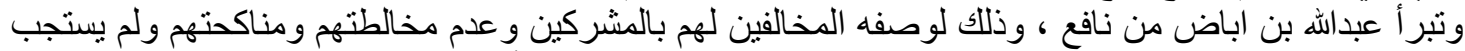

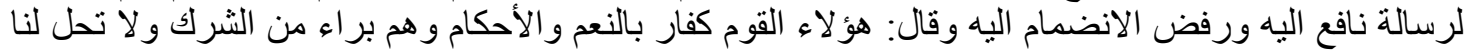

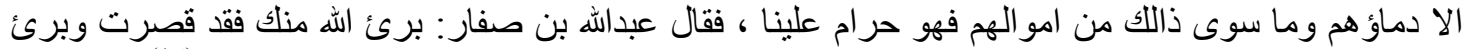

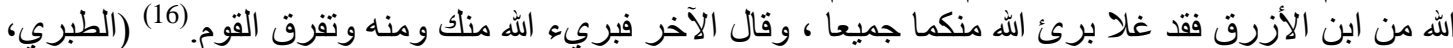

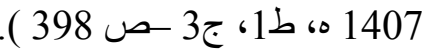

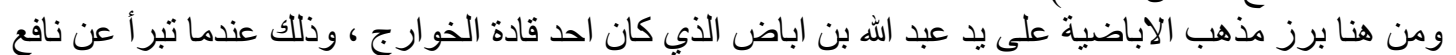

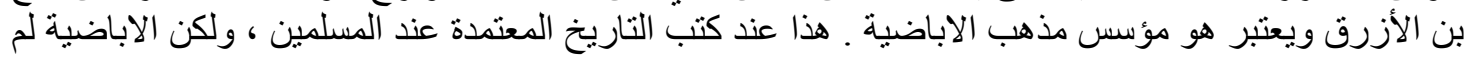

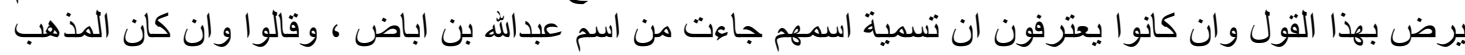

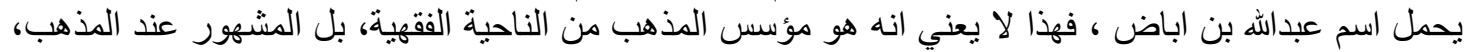

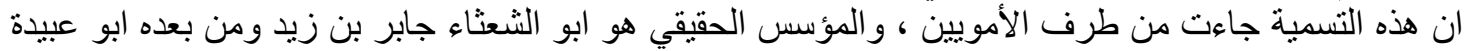

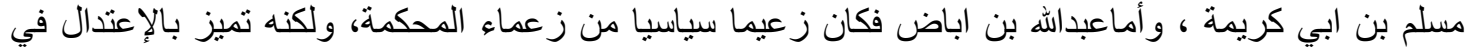

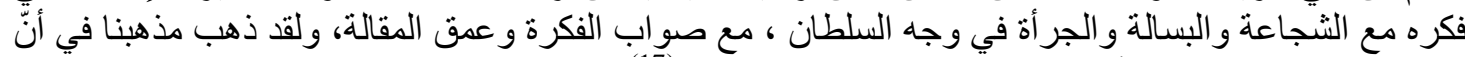

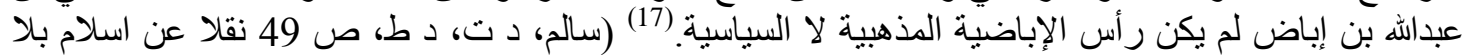

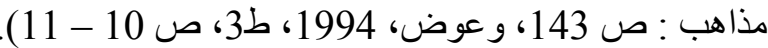
فقد ذهب كثبر من علماء الاباضية المتأخرين وفقاء هُ هم على أنّ عبداله بن إباض كان من أنباع ابي الثعثاء جابر

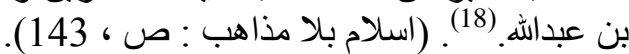

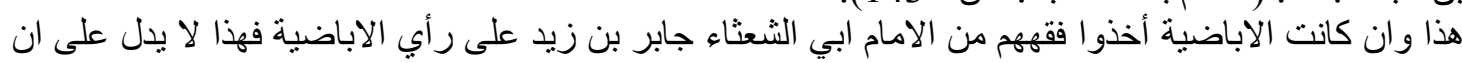

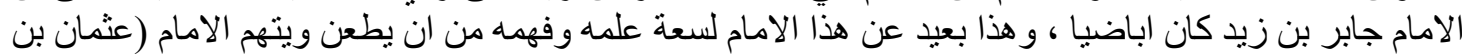

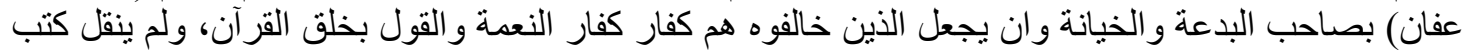

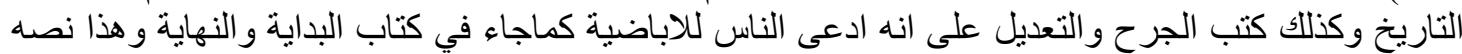

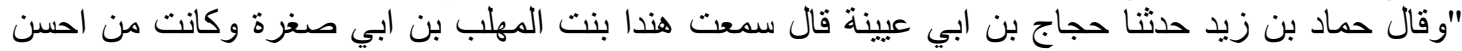

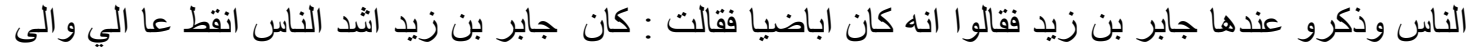

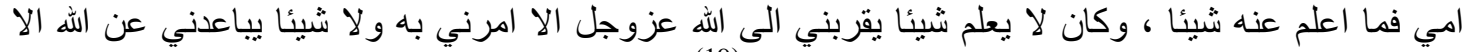

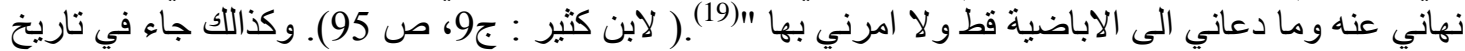
الكبير " وقال لنا علي حدثنا سفيان قلت لعمرو سمعت من ابي الثعثاء من امر الاباضية او شيبئا مما يقولون، فقال فئال 


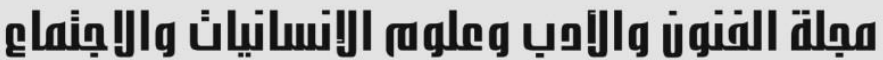

Journal of Arts, Literature, Humanities and Social Sciences www.jalhss.com

: ما سمعت منه شيئا قط وما ادركت احدا اعلم بالفتيا من جابر بن زيد "(204). ( البخاري، د ت، د ط، ج1،

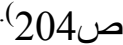

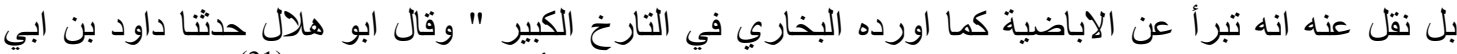

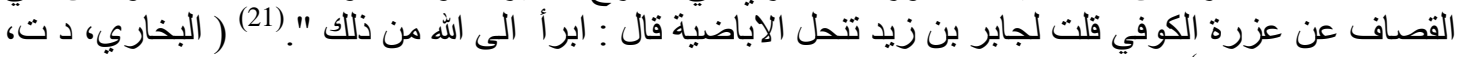

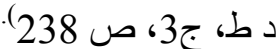
وكما جاء في تهذيب التهذيب " وقال داود بن ابي هند عن عزرة دخلت على جابر بن زيد فقلت إنّ هؤلاء و القوم

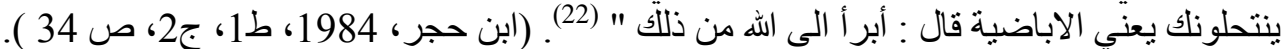

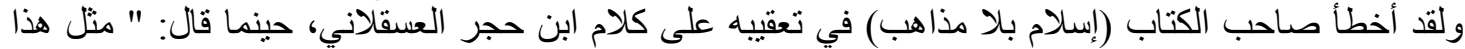

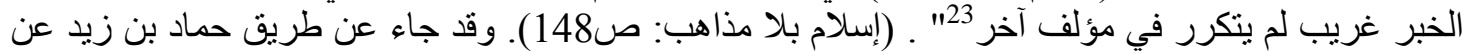

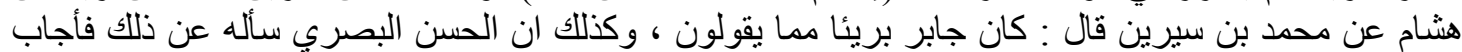

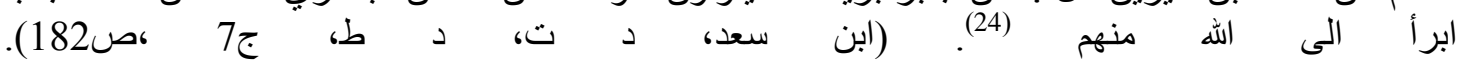

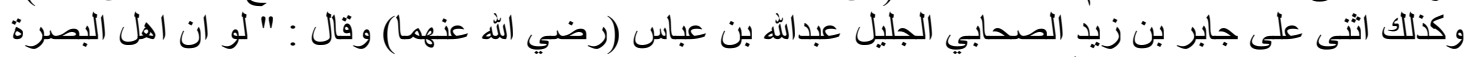

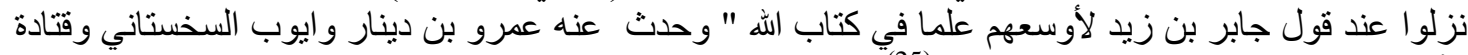

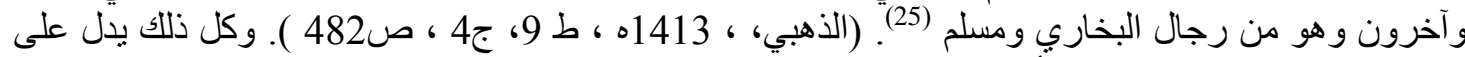
انه بريء من مذهب الاباضية لأن هؤلاء لا يروي احاديثهم عمّن يقدح في شخصية عثمان و علي (رضي الله

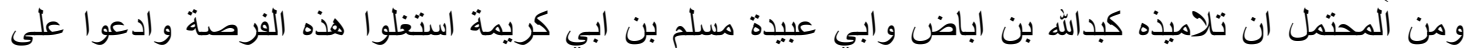

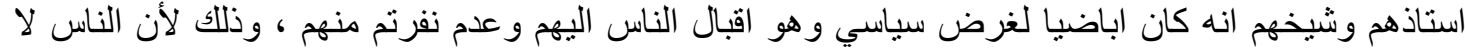

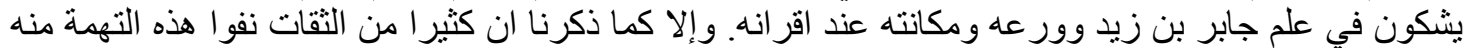
وتبرئه منهم. فأبو عبيدة مسلم بن ابي كريمة يعد واحدا من ابرز واهم فقهاء الاباضية لنشأة مذهبهم ونشره و اكثره هم تخريجا

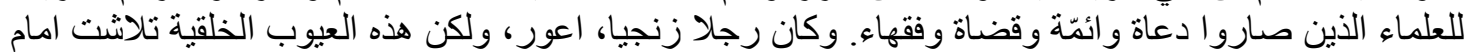

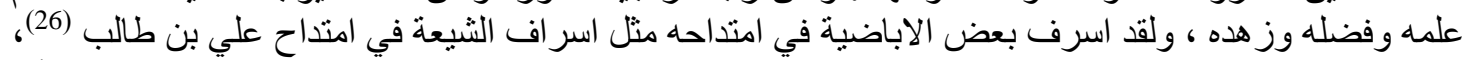

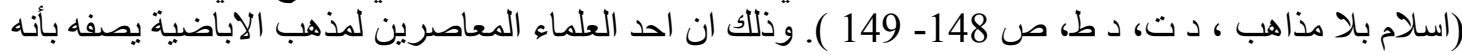

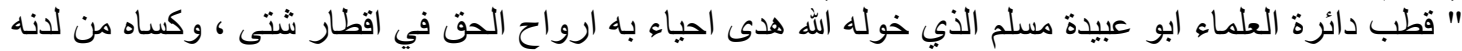

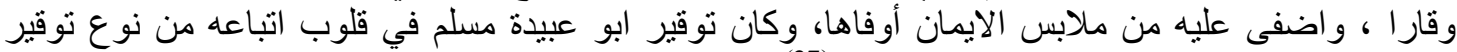

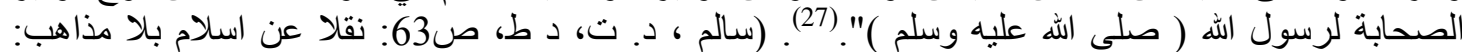

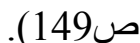

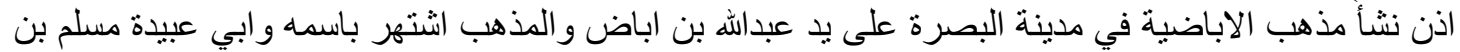

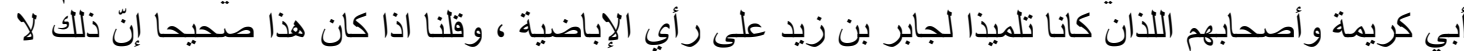
يدلّ على أنه كان إباضيا. 


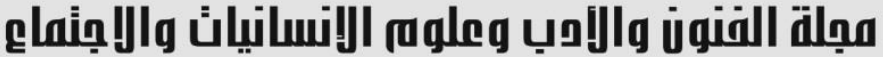

Journal of Arts, Literature, Humanities and Social Sciences www.jalhss.com

\section{المطلب الثاني

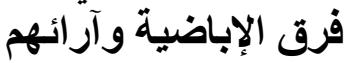

نذكر أو لا فرق الاباضية عند اصحاب المقالات التي يعتمد عليها المسلمون كثير الثم نذاضئ الذكر فرق الاباضية عند كتاب

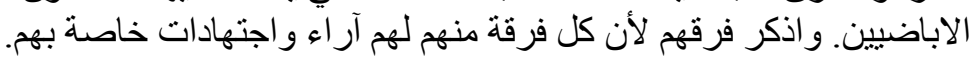

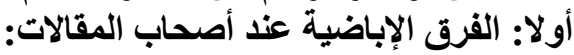

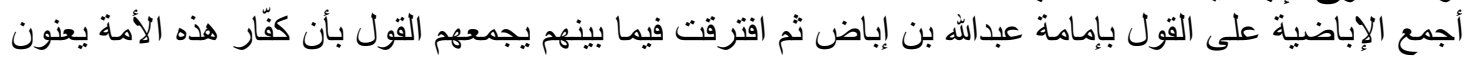

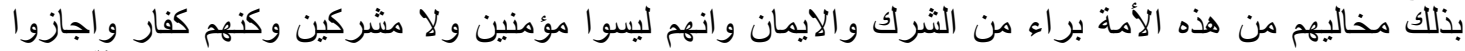

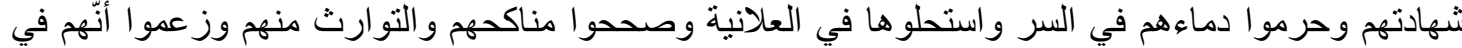

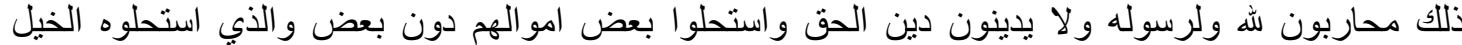

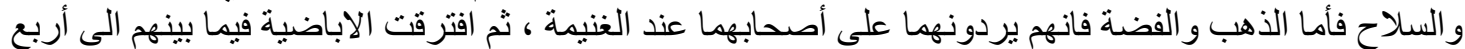

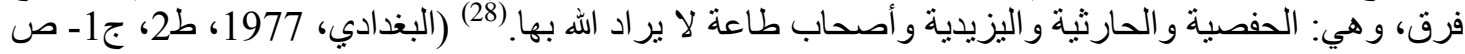

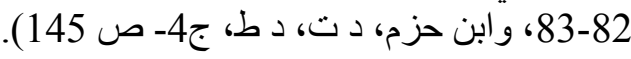

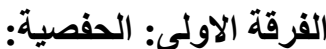

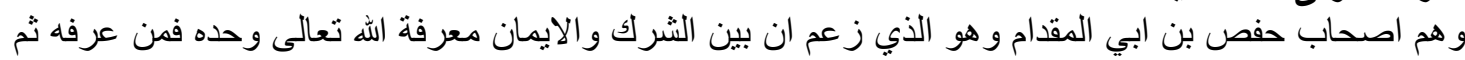

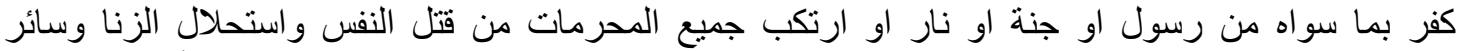

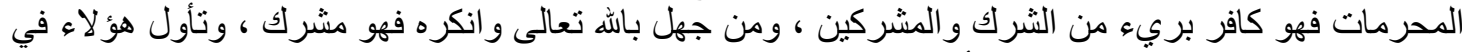

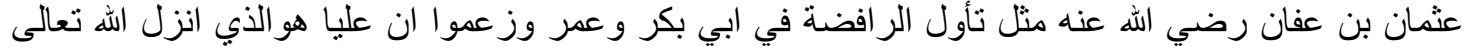

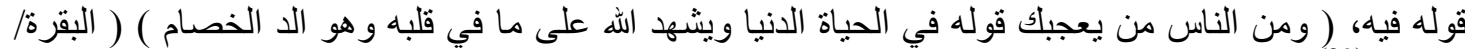

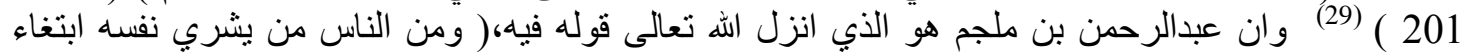

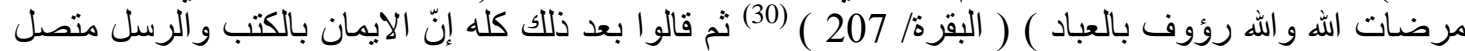

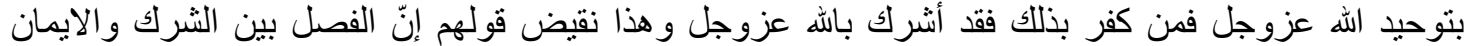

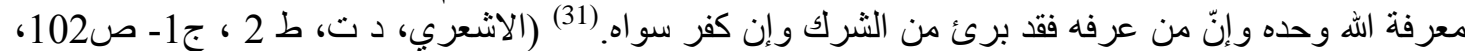

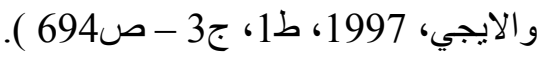

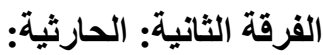

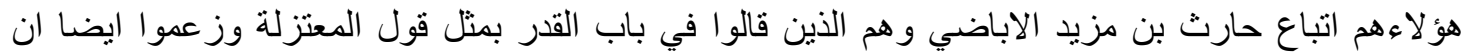

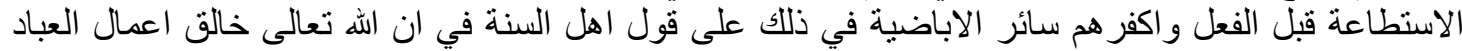

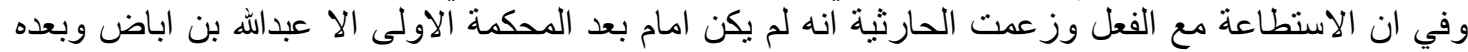

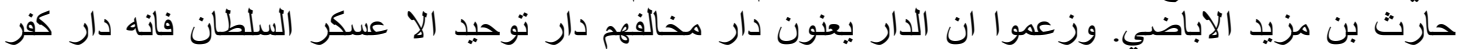

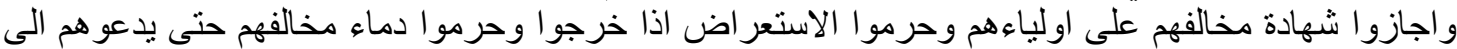

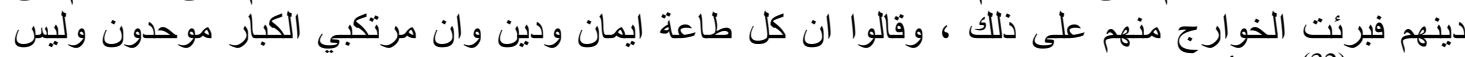

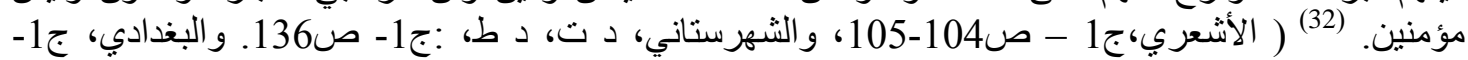

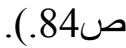

الفرقة الثالثة : اصحاب طاعة لا يراد الله بها:

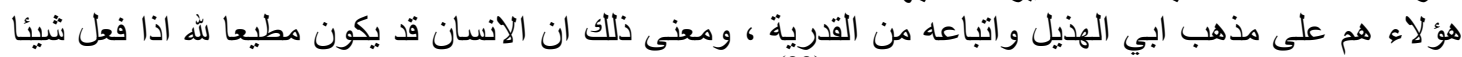

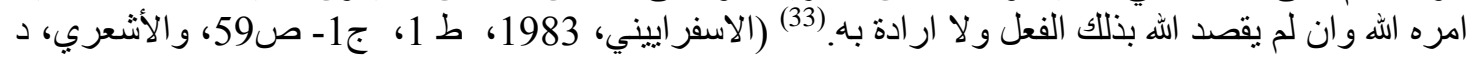

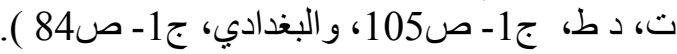

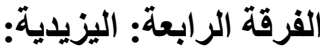

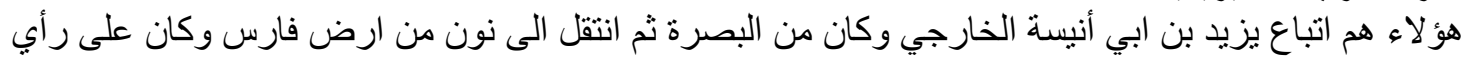

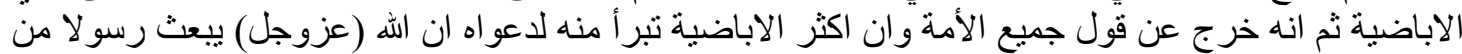




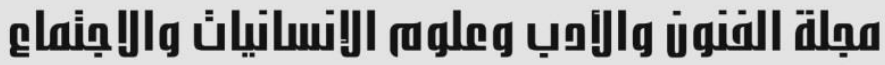

Journal of Arts, Literature, Humanities and Social Sciences www.jalhss.com

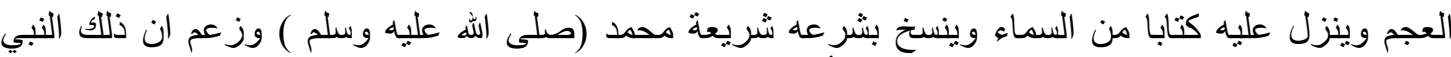

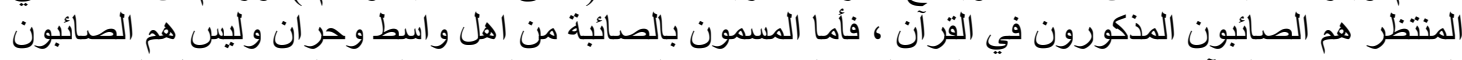

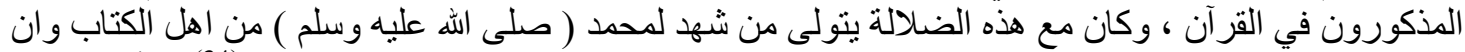

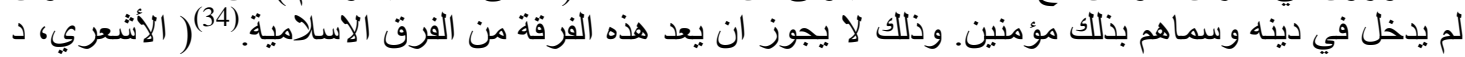

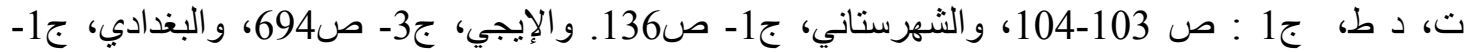

ولقد أحصى كتّّب الاباضية أهمّ الفرق الإبة التي لها علاقة بمذهب الاباضي فوجدها ست فرق وهي: النكارية والنفانثية

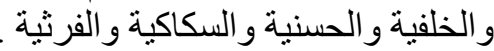

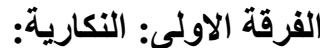
ظهرت هذه الفرقة بعد وفاة عبدالرحمن بن رستم الفارسي زعيم الاباضية وامامهم بتاهرت عندما رشح قبل وفئ وفاته

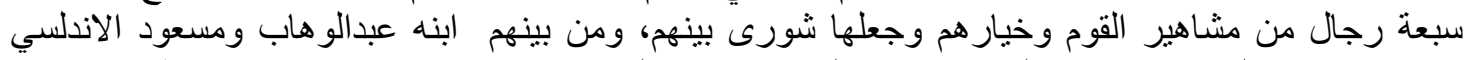

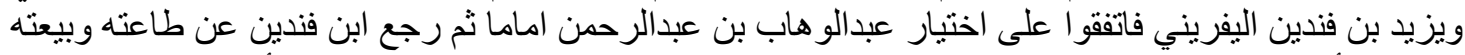

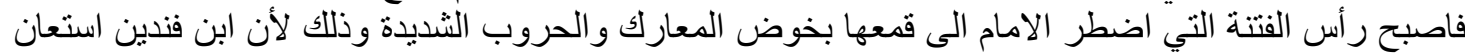

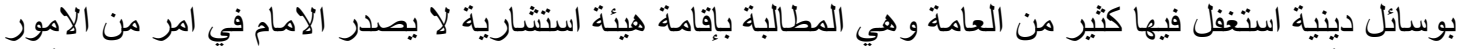

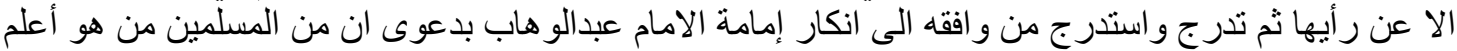

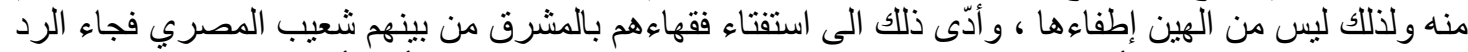

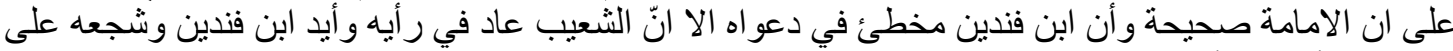

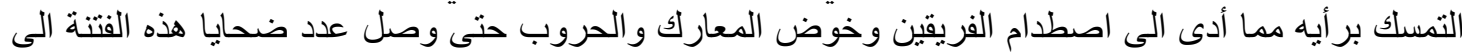

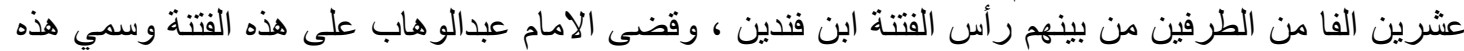

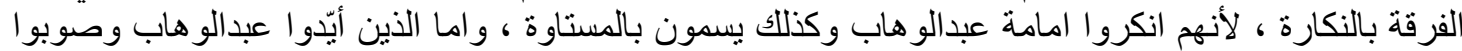

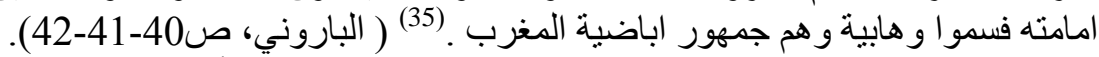

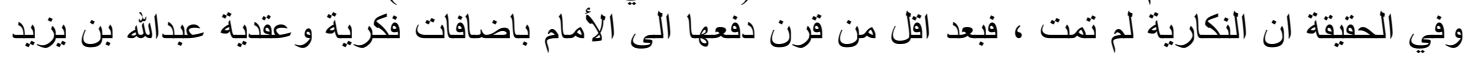

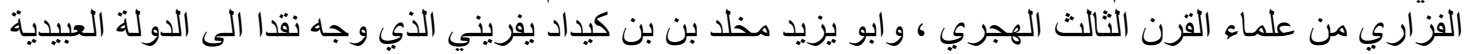

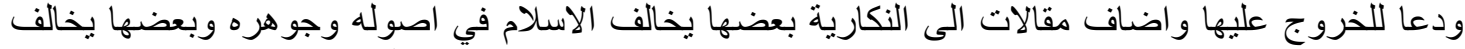

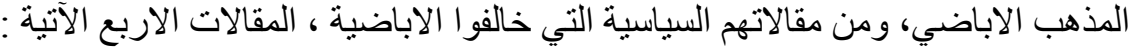

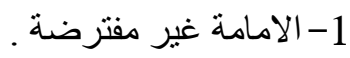

2- 2 - صلاة الجمعة غير جائزة وراء أئمة الجور. 3- - مطايا الملوك لا يحلّ أخذها.

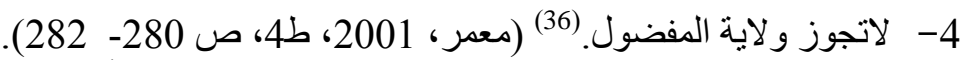

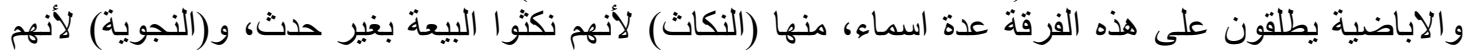

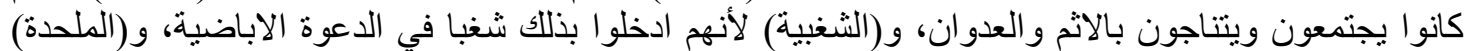

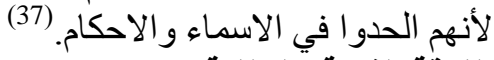

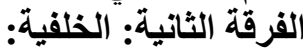

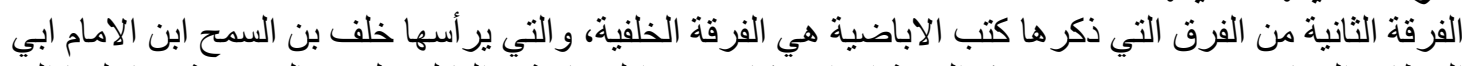

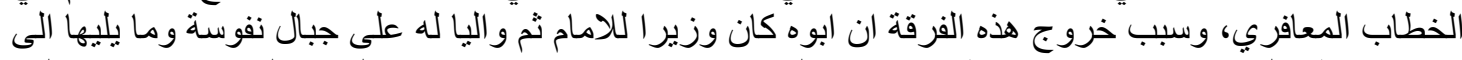

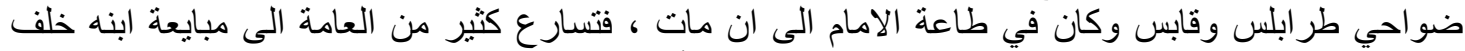

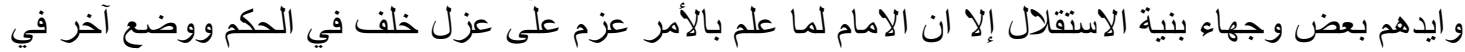

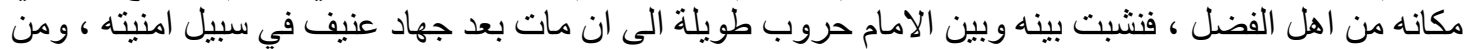

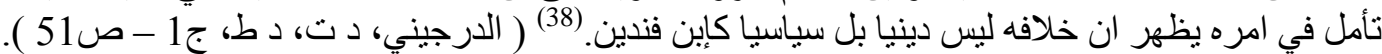

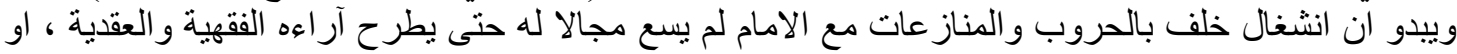

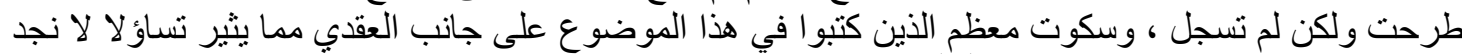

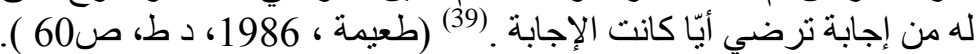




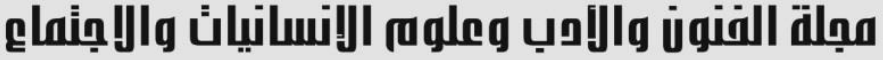
www.jalhss.com

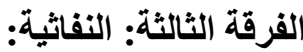

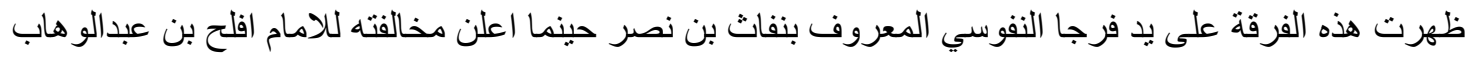

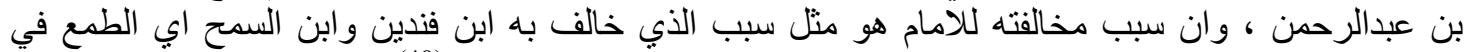

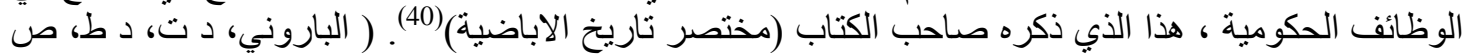

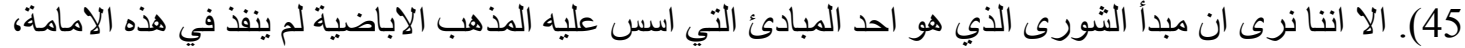

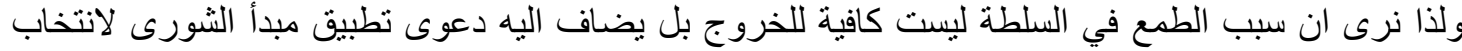

ومن عقائد هذه الفرقة التي دعا اليها هي :

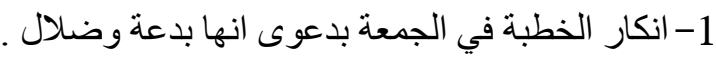

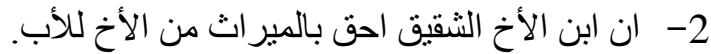

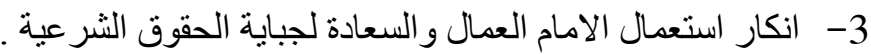

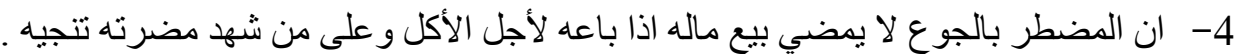

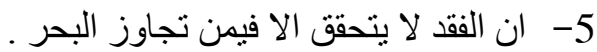

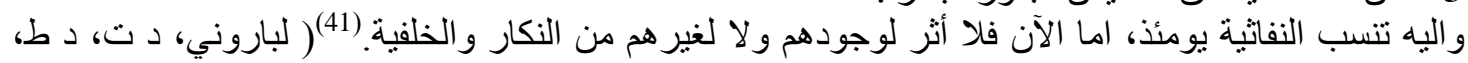

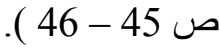

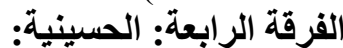
ظهرت هذه الفرقة في طر ابلس في قرن الثالث الهجري على يد ابو زياد الحئ الحمد بن الحسين الطر ابلسي الذي ينسب

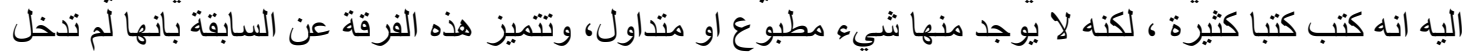

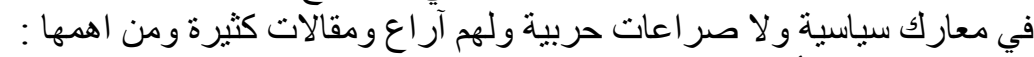
1 - 1 - لا يشرك من أنكر سوى الله.

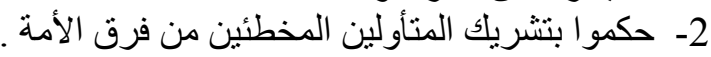

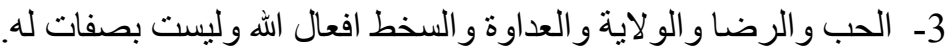

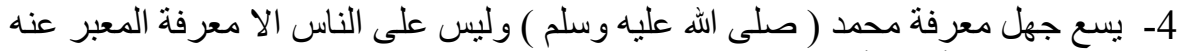

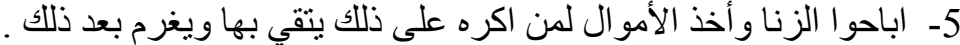
6- - الحر ام المجهول معاقب عليه.

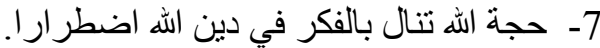

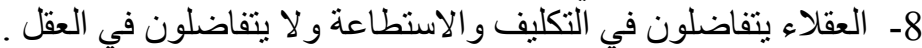

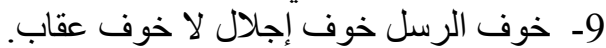
10- تجوز الو لاية و البراءة بشريطة.

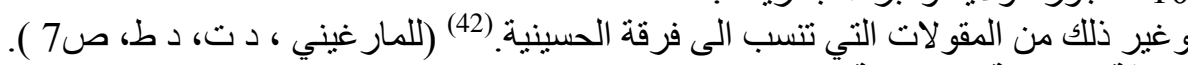

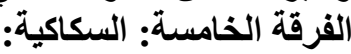

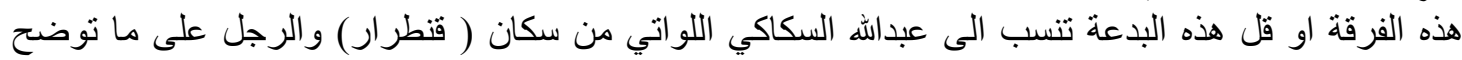

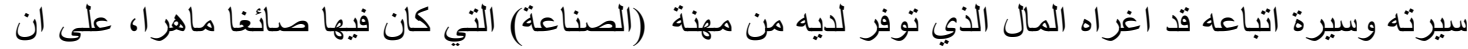

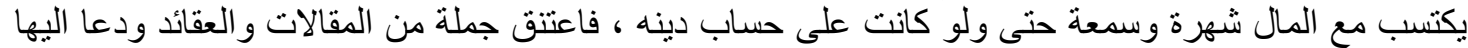

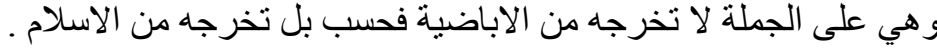

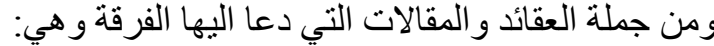

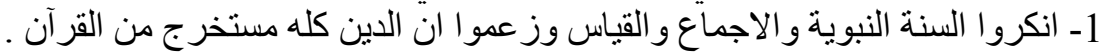

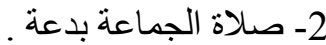
3- و الأذان للصلاة بدعة فإذا سمعوا قالو ا : نهق الحمار ـ نعوذ باله مما يقولون .

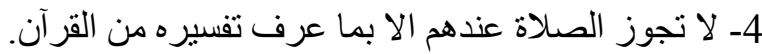

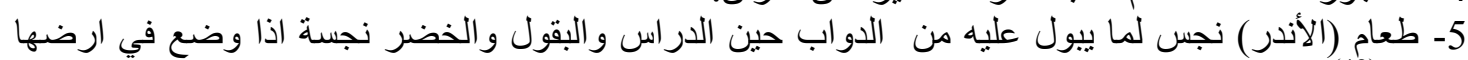

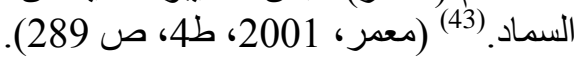




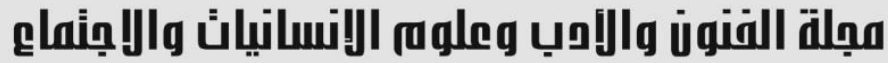

Journal of Arts, Literature, Humanities and Social Sciences www.jalhss.com

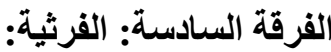

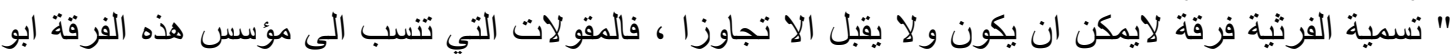

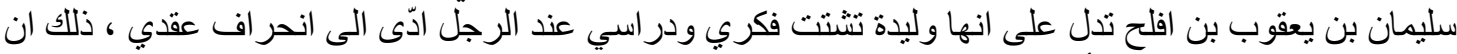

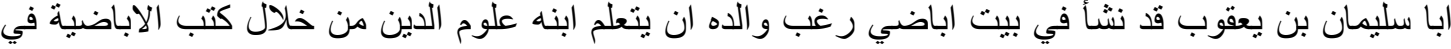

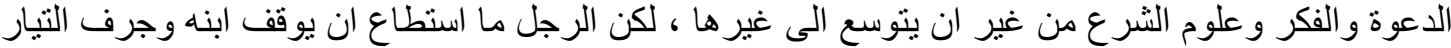

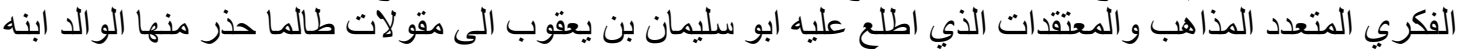

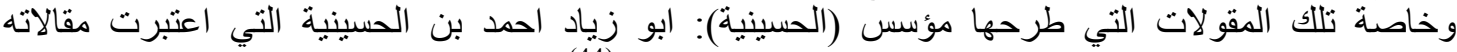

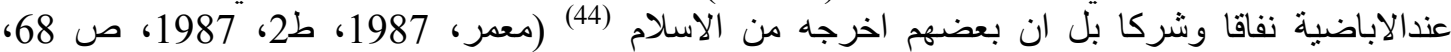

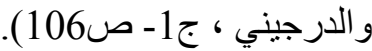

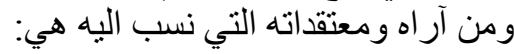

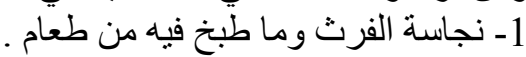
2- 2 - 2 - تحريم اكل الجنين. 3- تحريم دم العروق ولو الجنين بعد غسل المذبح وكذلك دم الجوف.

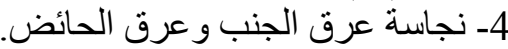

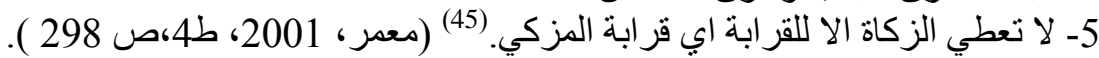

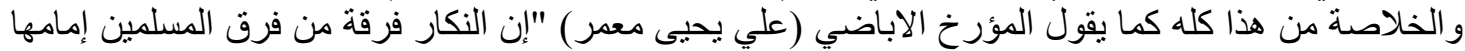

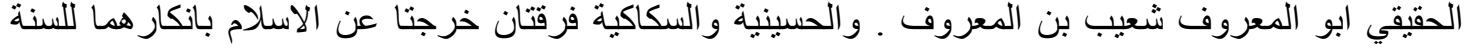

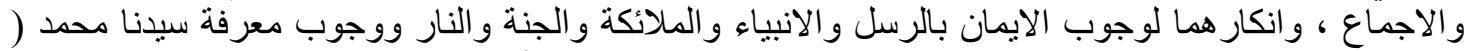

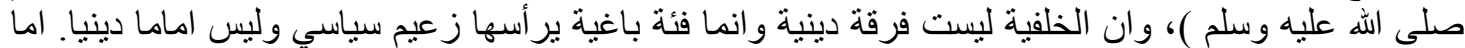

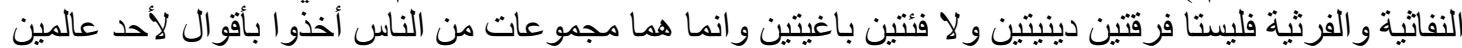

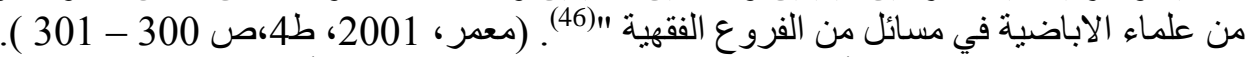

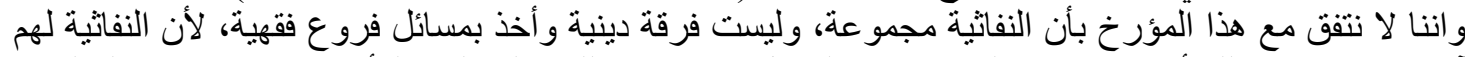

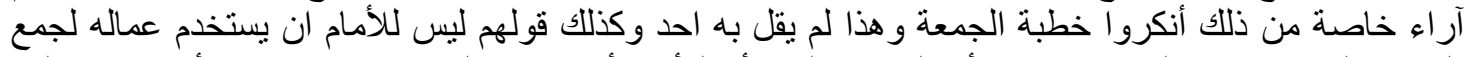

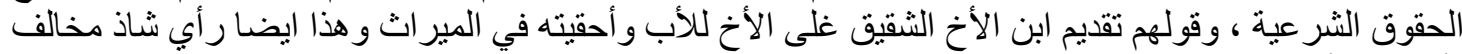

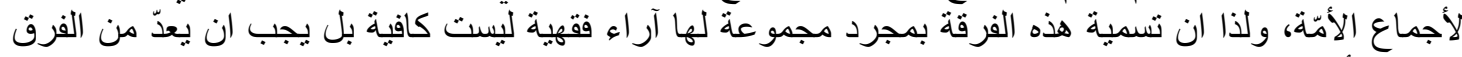

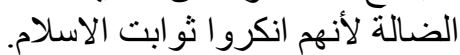

\section{المطلب الثالث \\ أصول مذهب الإباضية الاعتقادية المبالية}

إن الاباضية كباقي المذاهب و الفرق لهم جملة اصول تتفقون في بعضها مع اهل السنة وتخالفون في بعضها.

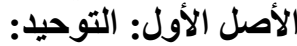

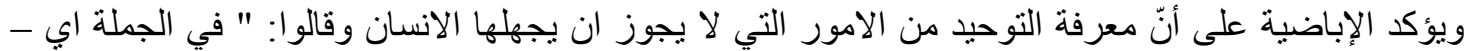

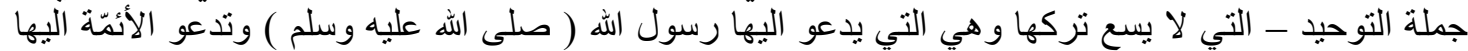

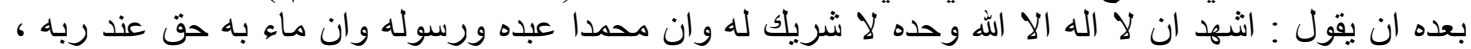

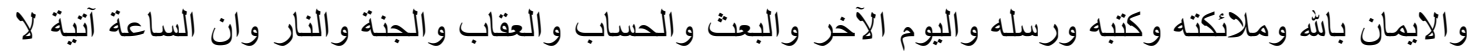

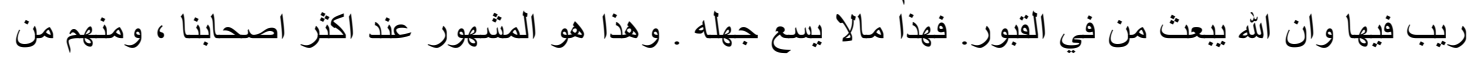

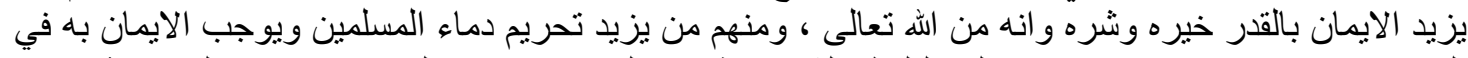

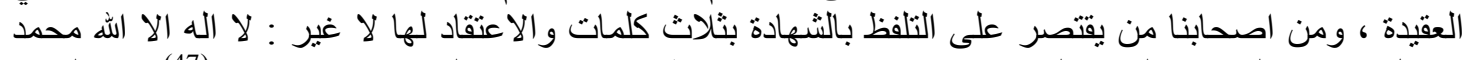

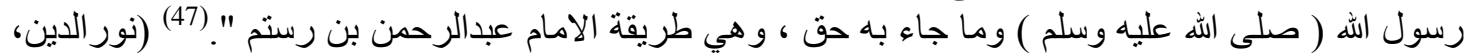

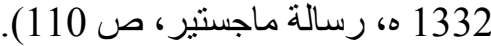
وقال صاحب الكتاب " دراسات الاسلامية في اصول الاباضية " بعد ان جاء بجملة من الآراء للشيو الآن الاباضية:

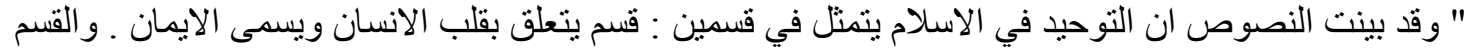

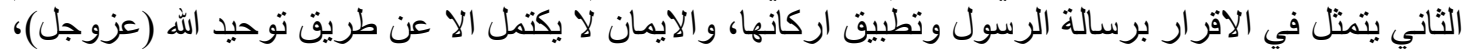

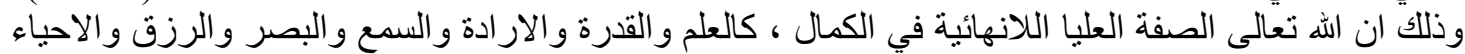




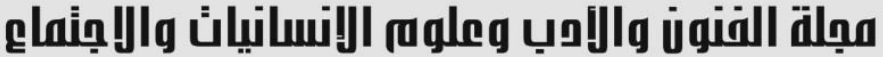

Journal of Arts, Literature, Humanities and Social Sciences www.jalhss.com

والاماتة وانه تعالى لا يماتله فيها ولا في ذاته مقدار من المقادير الموجودة في الدنيا ولا في الآخرة. وبينت

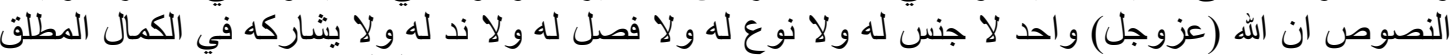

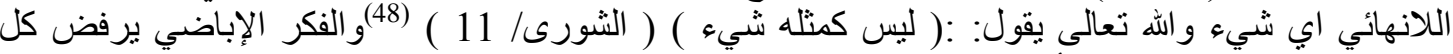

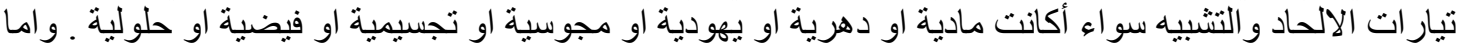

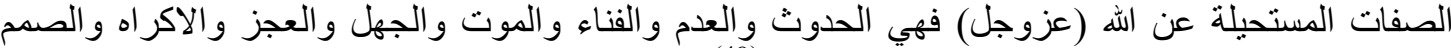

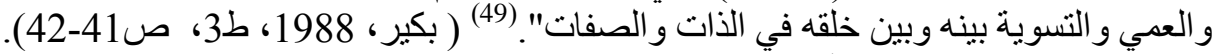

الاصل الثاني: الصفات الالهية:

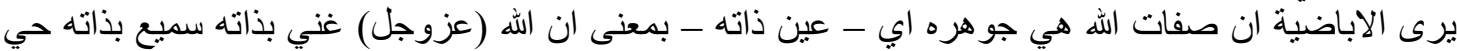

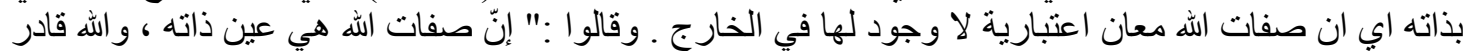

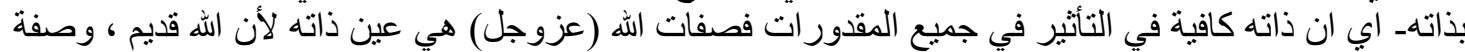

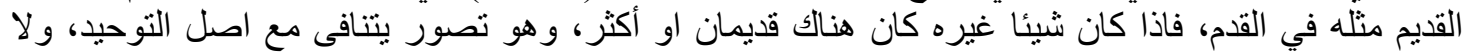

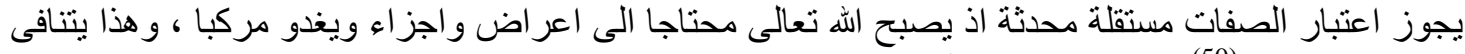

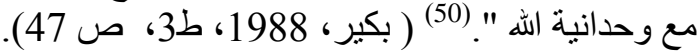

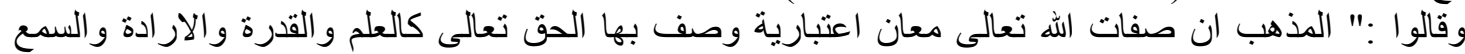

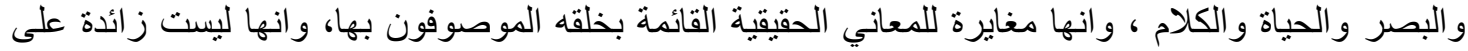

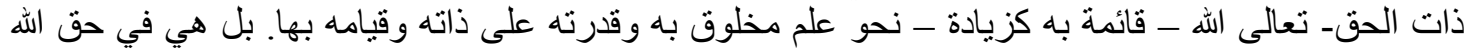

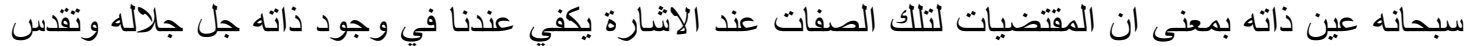

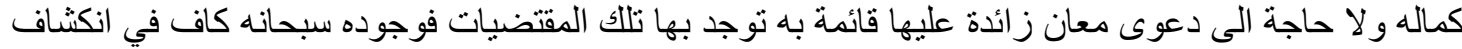

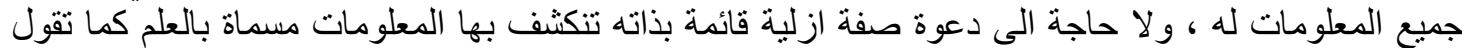

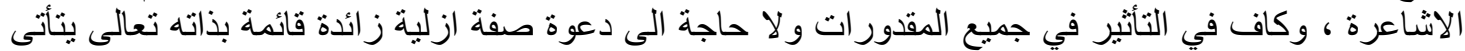

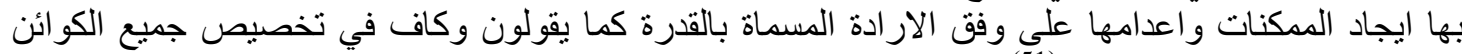

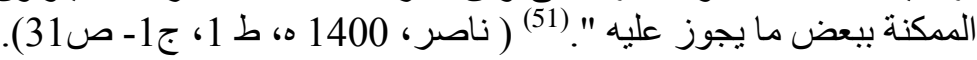

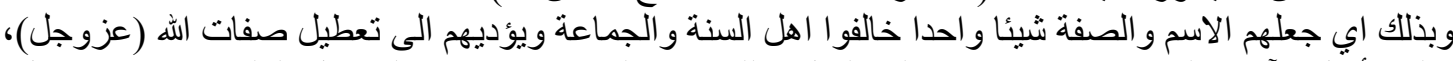

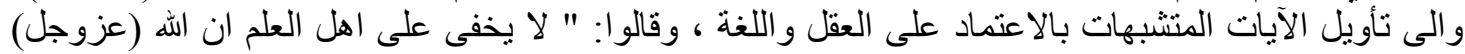

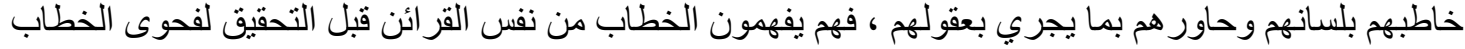

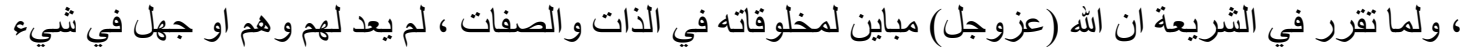

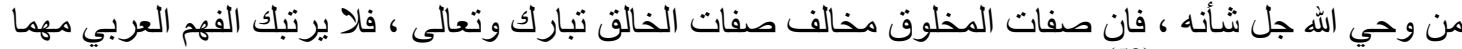

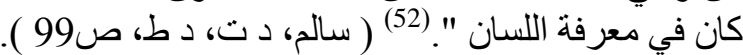

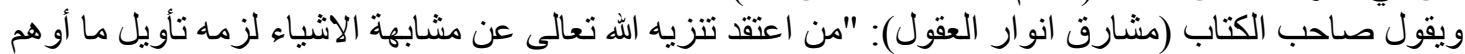

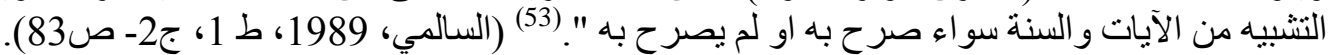

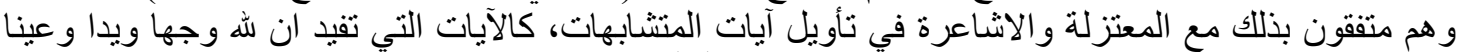

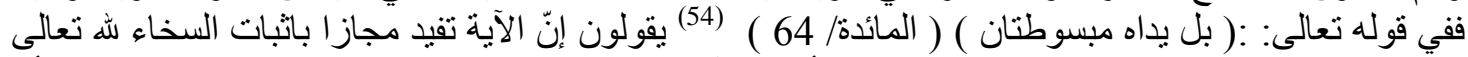

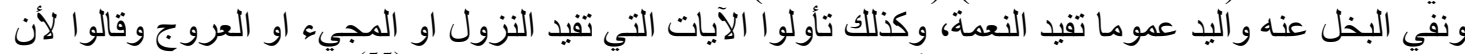

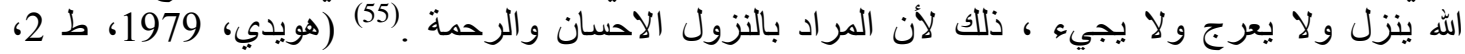

ص113) (113)

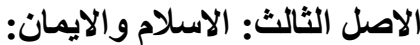

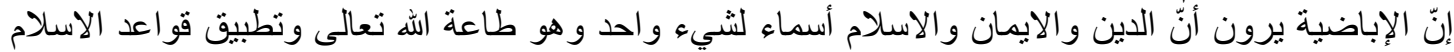

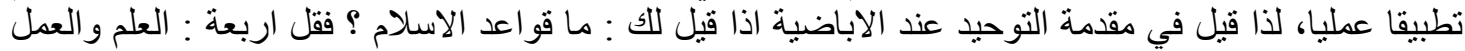

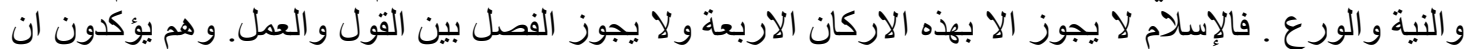

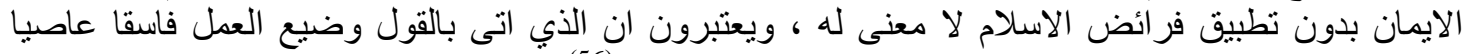

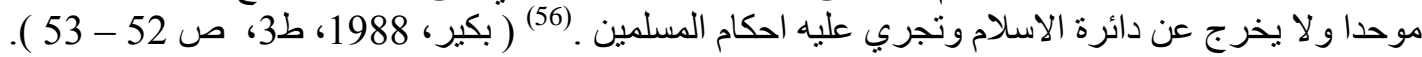

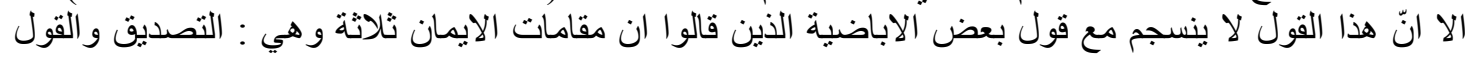

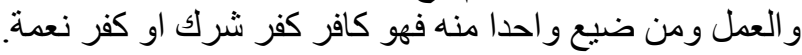




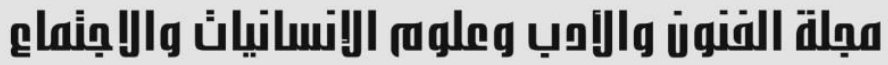

Journal of Arts, Literature, Humanities and Social Sciences www.jalhss.com

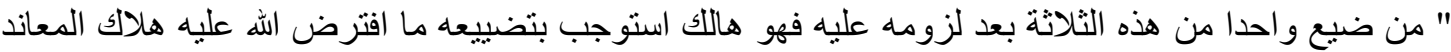

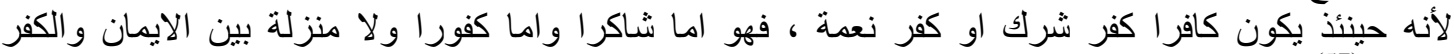

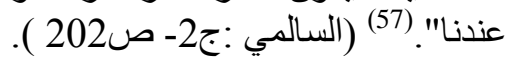

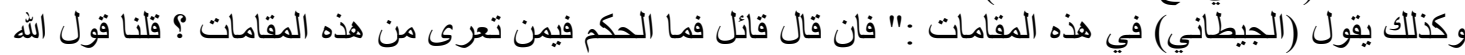

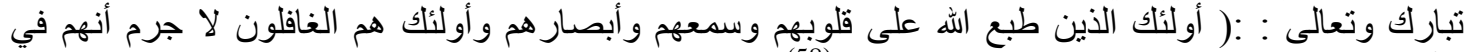

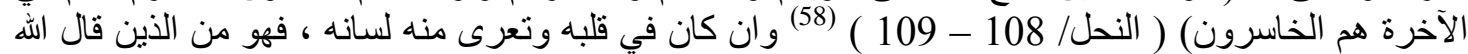

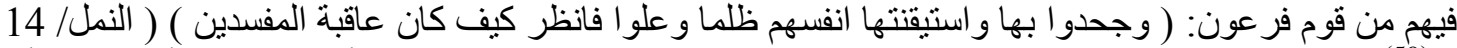

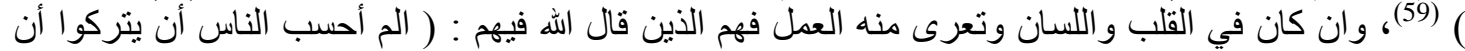

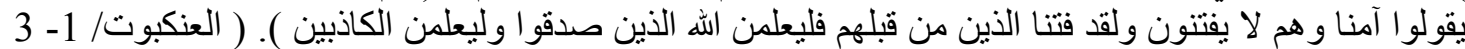

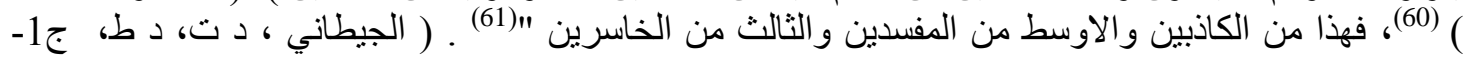

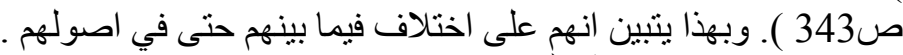

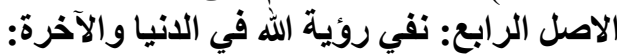

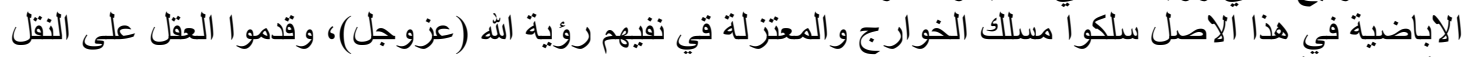

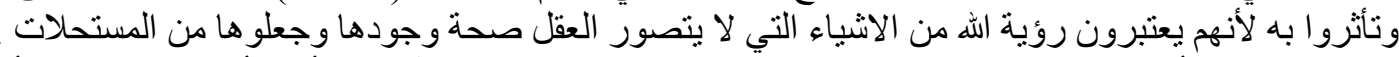

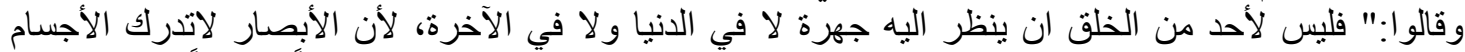

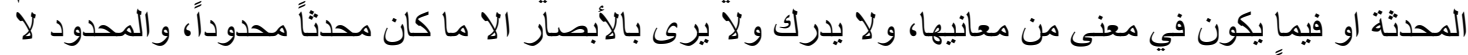

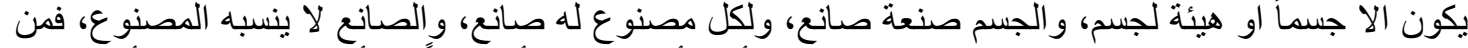

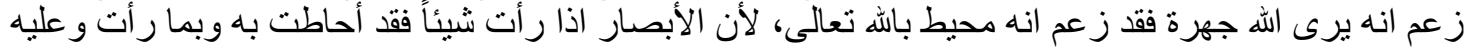

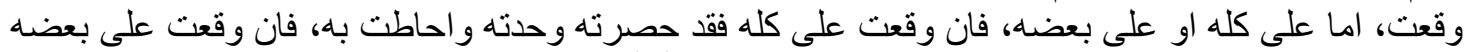

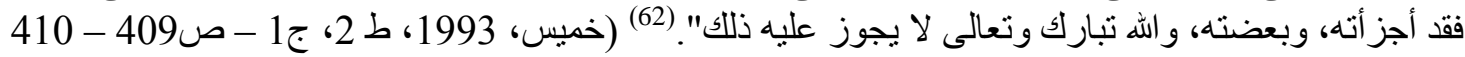

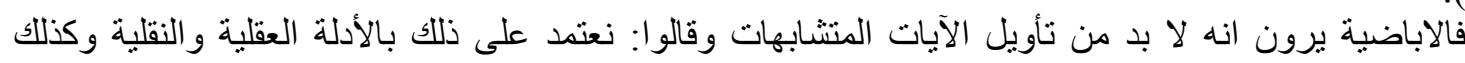

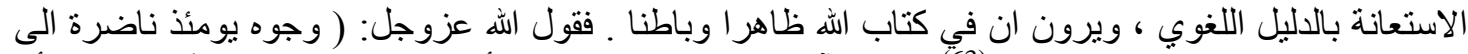

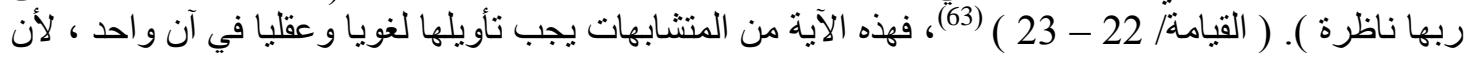

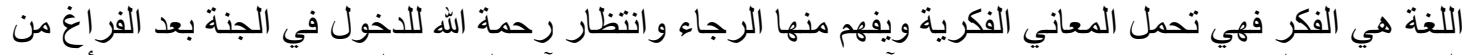

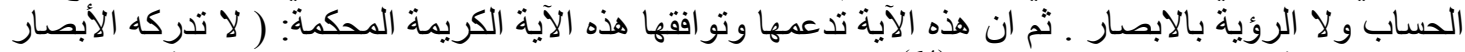

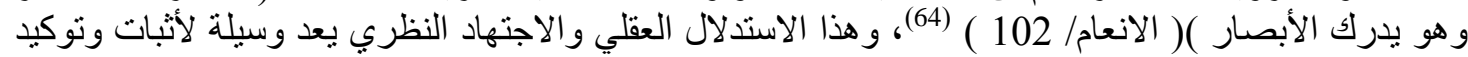

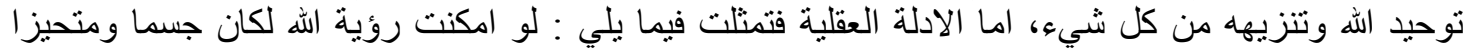

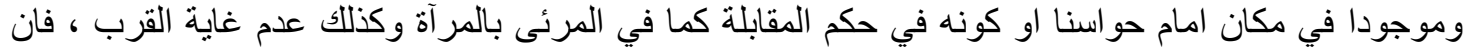

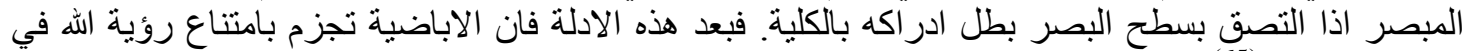

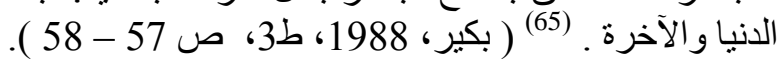

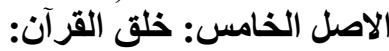

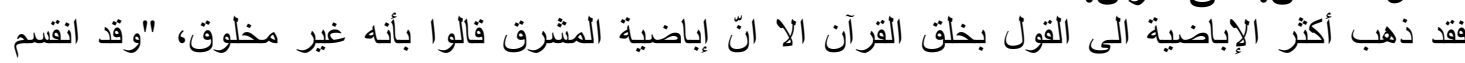

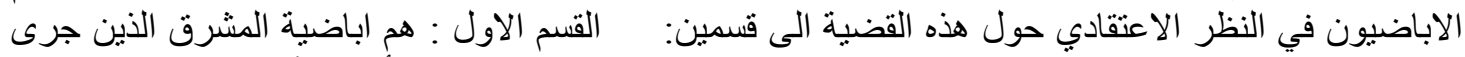

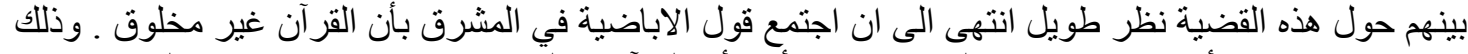

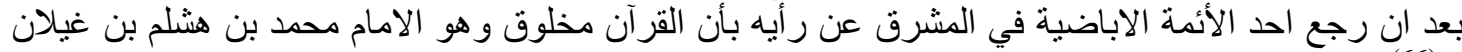

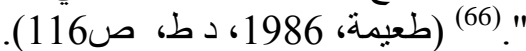

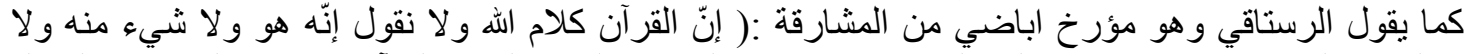

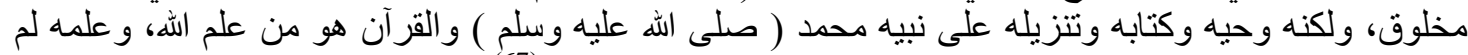

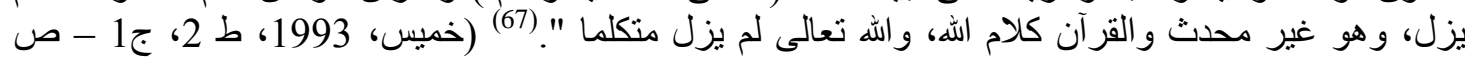

أمّا الآخرون فيرون انّ القرآن مخلوق، لأنّ اله خالق كل شيء، و القرآن شيء من الآشياء ويستدلون بأثنياء منها:

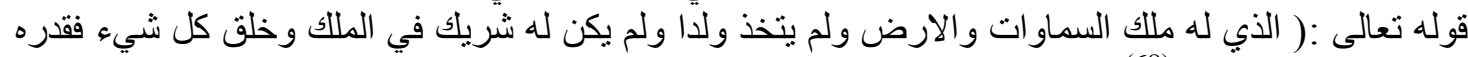

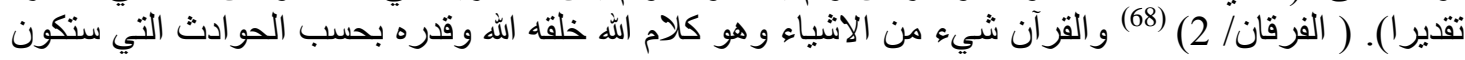




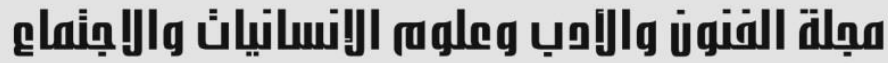

\author{
Journal of Arts, Literature, Humanities and Social Sciences
} www.jalhss.com

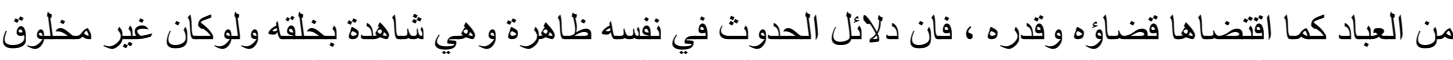

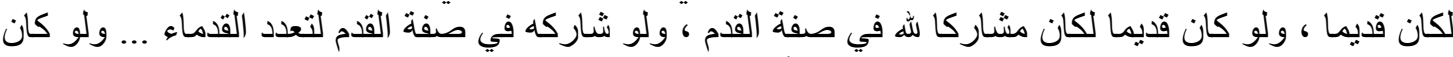

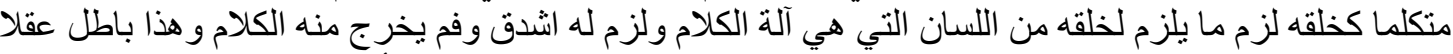

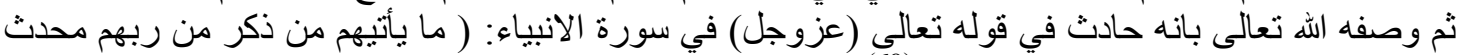

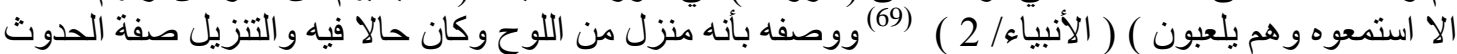

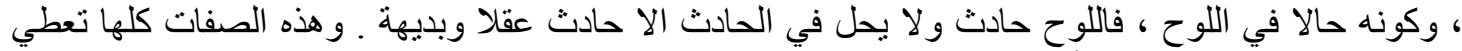

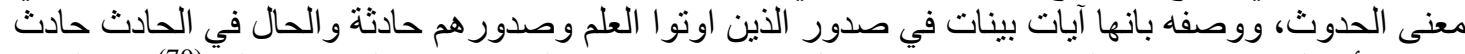

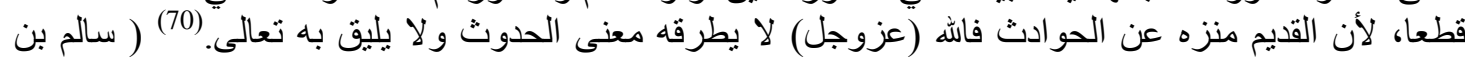

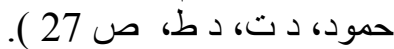

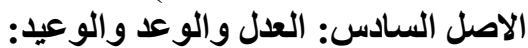

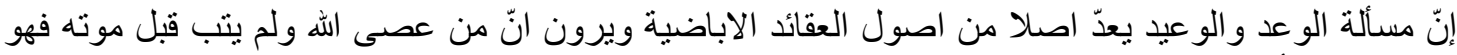

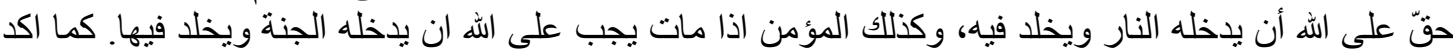
صاحب الكتاب (مشار الانوار العقول ) بقوله:

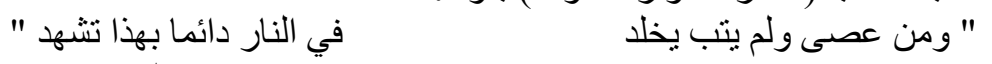

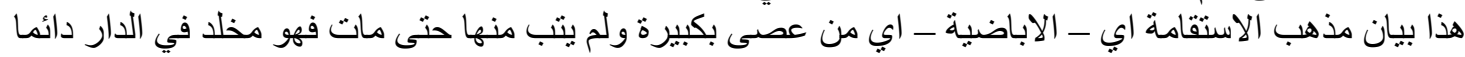

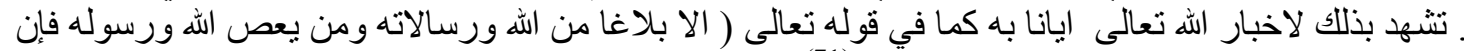

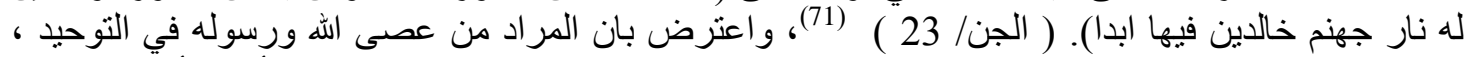

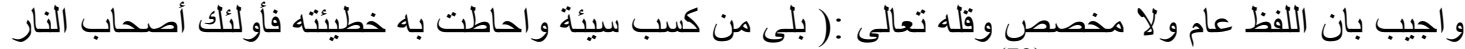

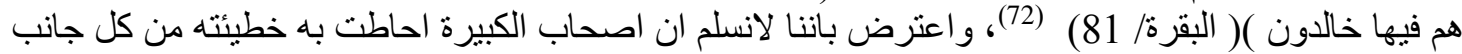

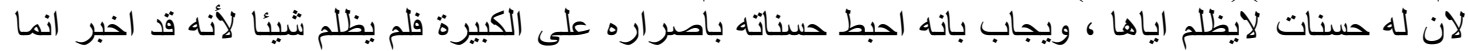

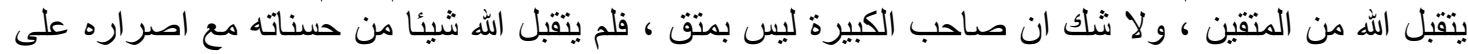

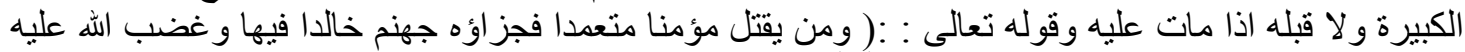

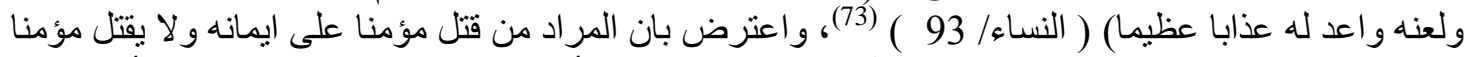

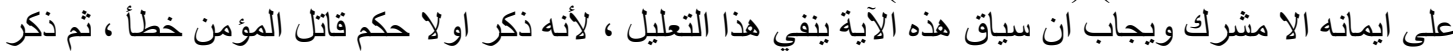

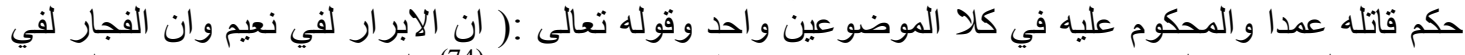

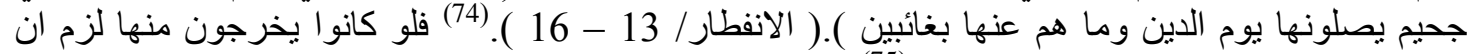

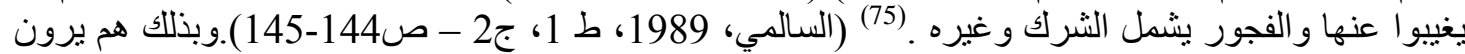

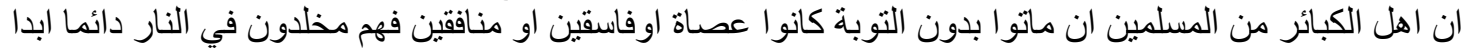

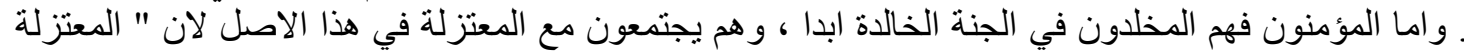

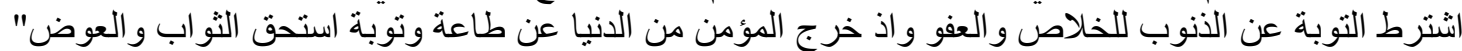

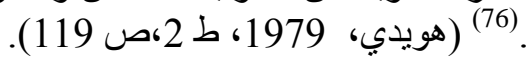

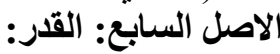

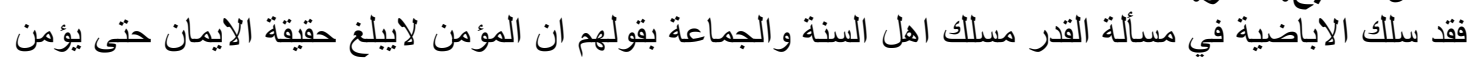

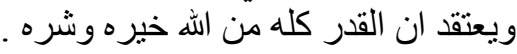
ولم يجز اغر اقنا فيه النظر

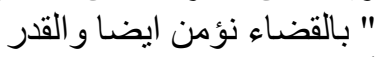

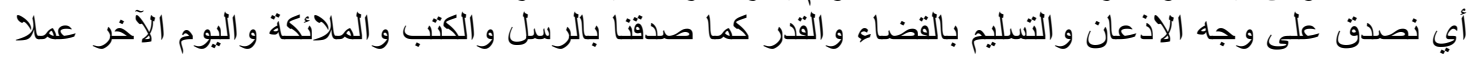

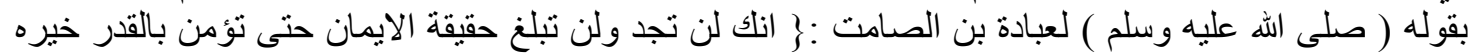

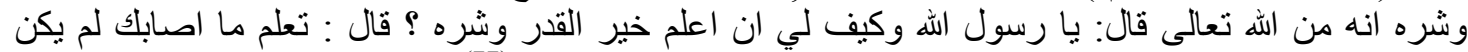

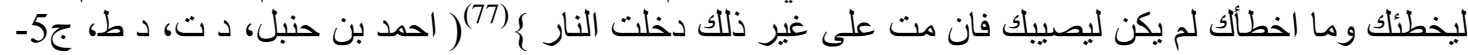

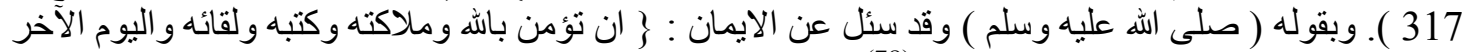

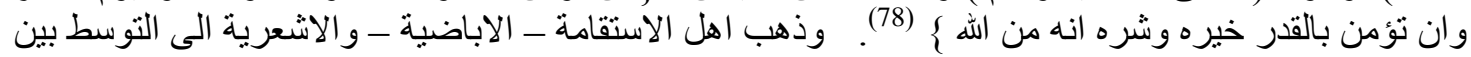

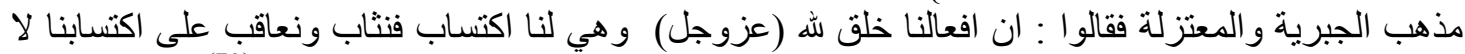

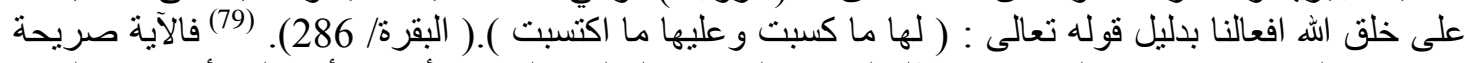

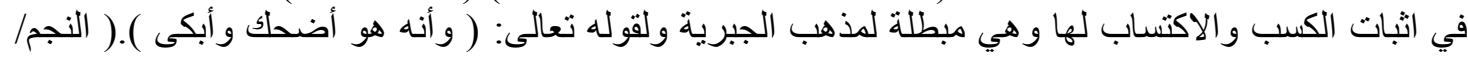




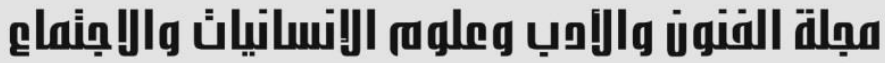

Journal of Arts, Literature, Humanities and Social Sciences www.jalhss.com

43 ) (80)، فالآية صريحة على ان الله تعالى هو خالق الضحك و البكاء فيهم وهو فعل لهم وهذا مبطل لمذهب

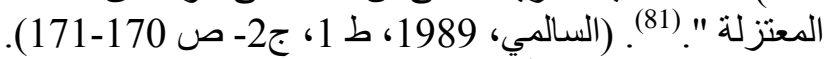

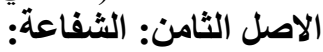

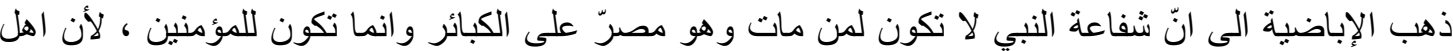

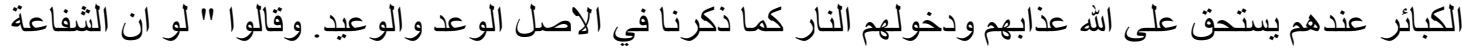

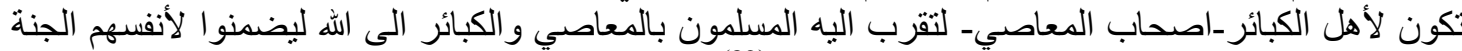

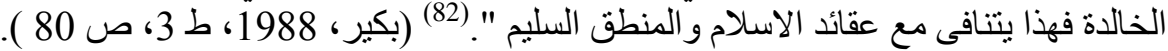
الاصل التاسع: لا منزلة بين منزلتين: ترى الاباضية الى من انى بكبيرة كافر اما كفر نعمة او كفر جحود وبهذا ينفون منزلة بين منزلتين ويختلفون في

$$
\text { وبالنفاق الثاني منهما وسم }
$$

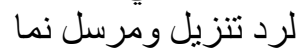

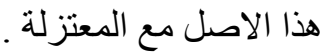

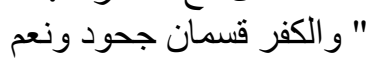

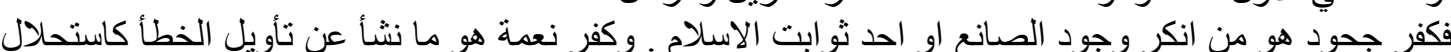

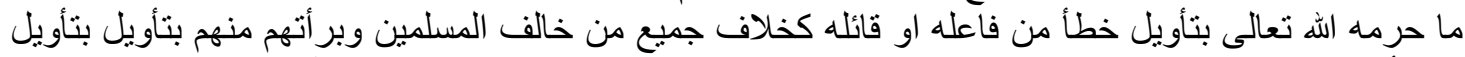

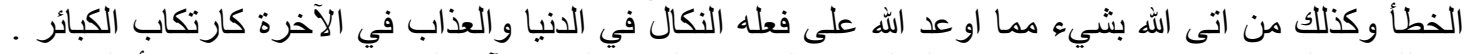

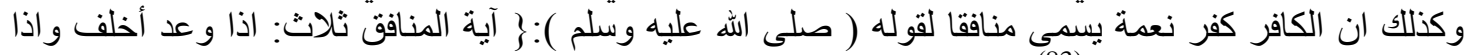

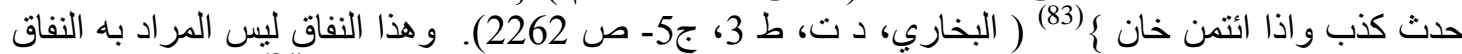

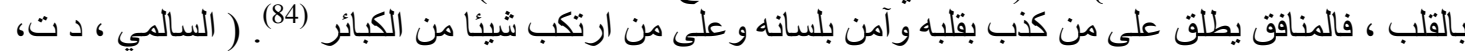

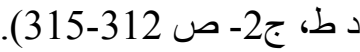

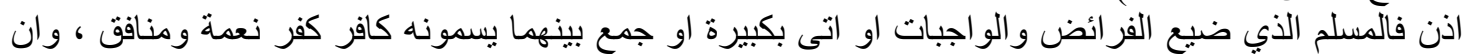

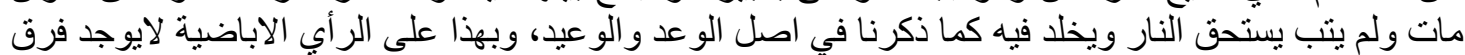

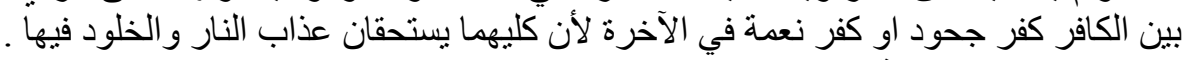

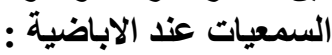

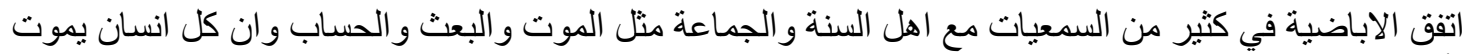

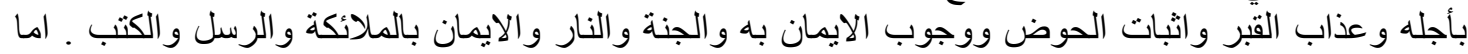

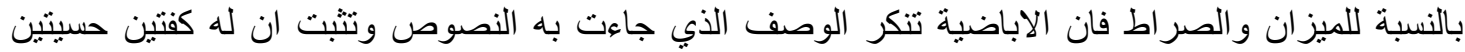

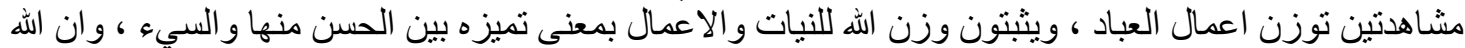

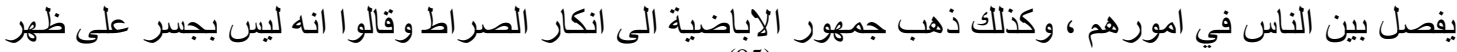

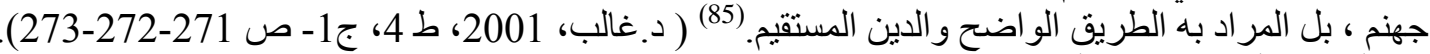
قضية الخلافة عند الاباضية:

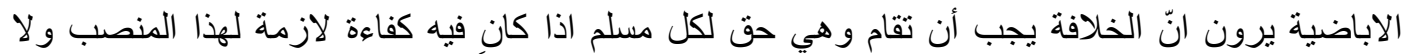

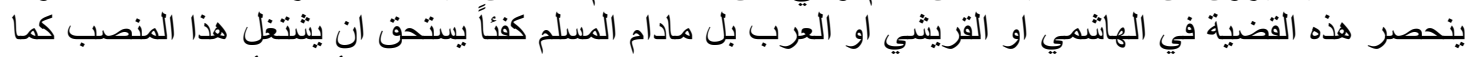

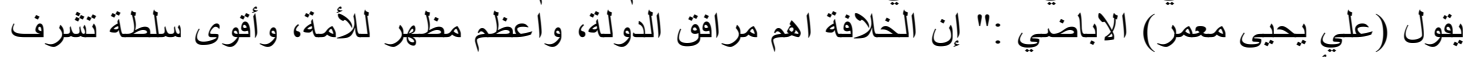

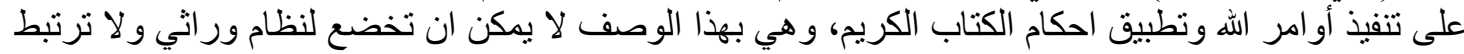

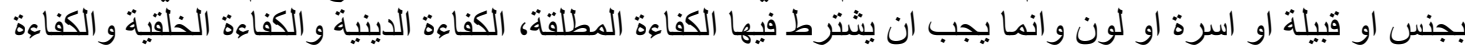

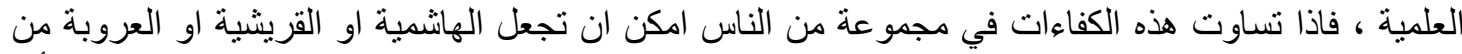

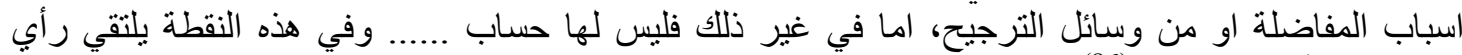

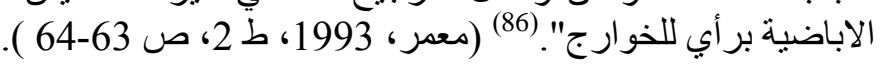

الخاتمة

لقد توصل الباحث من خلال هذا البحث الى النتائج الآتية:

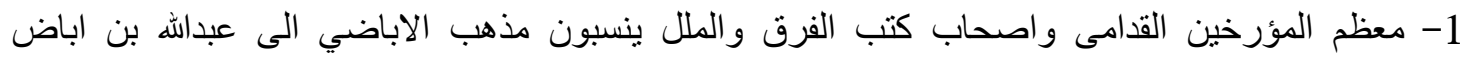

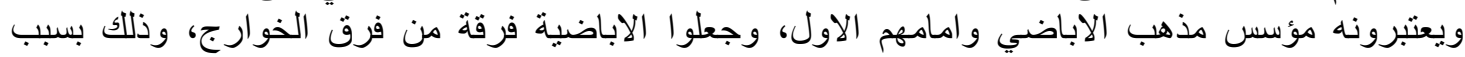




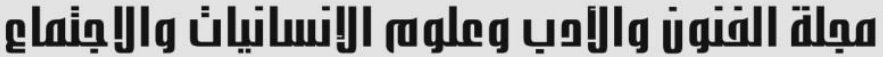

Journal of Arts, Literature, Humanities and Social Sciences www.jalhss.com

الاصول التي اعتنقها الاباضية من الخوارج و التزم بها من تكفير مرتكب الكبيرة ان لم يتب قبل موته، و عدم رؤية الله في الدنياو الآخرة، وموقفهم من الصحابة ون ورميهم بالخيانة.

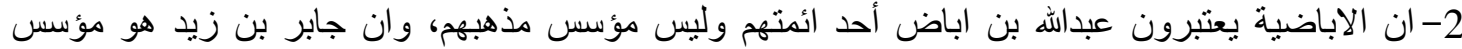
المذهب و امامهم الاول، ويكر هون تسميتهم بالخوارج ويصفون انفسه بأهل الحق و الاستقامة.

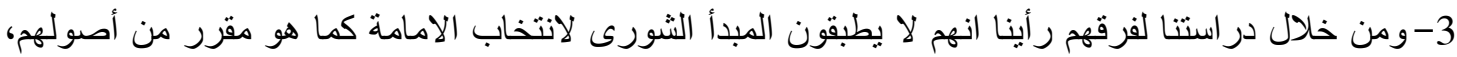
وجعلوه سببا للخروج على الامام في فترة الدولة الاموية و العباسية.

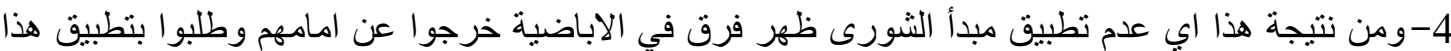

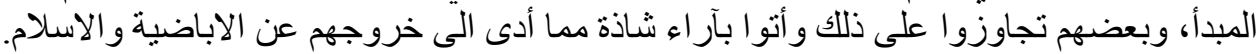

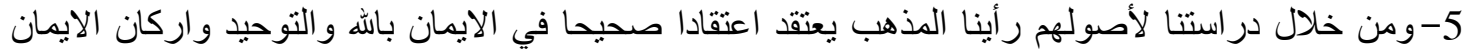

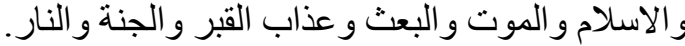
6-ذهب الاباضية الى ابطال شفاعة الرسول ( صلى الله عليه وسلم )لأهل الكبائر وخالفوا بذلك أهل السنة و الجماعة، وذللك يعود لتمسكهم بأصل الو الوعد و الو عيد.

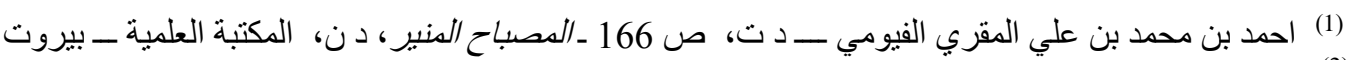

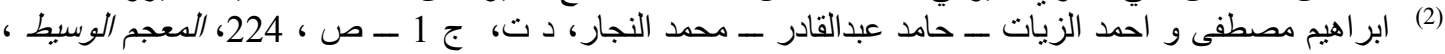

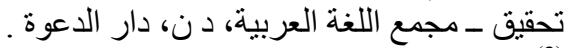

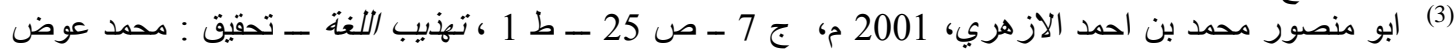

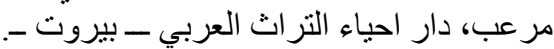

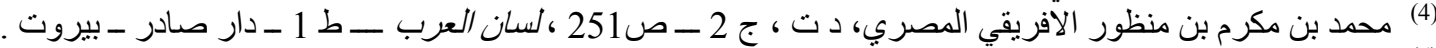

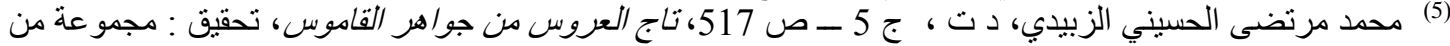
المحققين، دار الهداية (6) الثهرستاني: محمد بن عبدارلئن الكريم بن ابي بكر احمد الثهرستاني المتوفى 458 هـ ـ تحقيق : محمد سيد كيلاني: 1404،

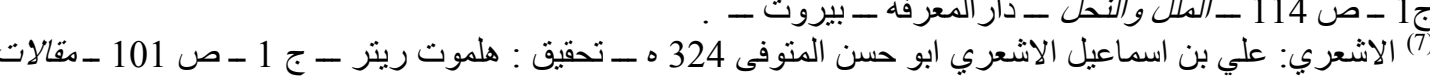

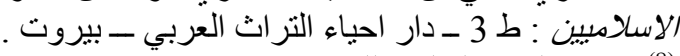

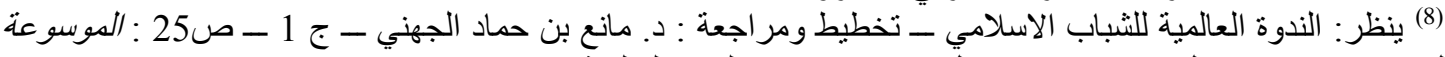

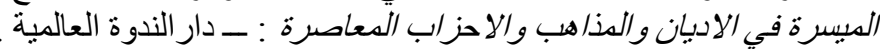

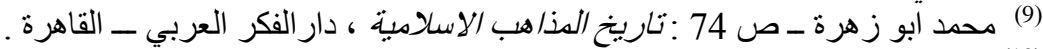

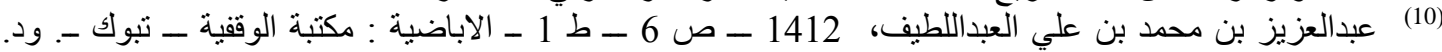

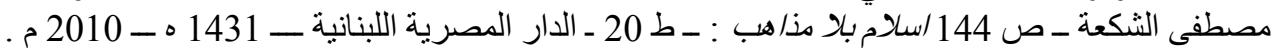

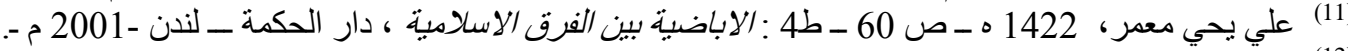

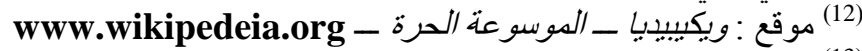
(13): ابن كثير، اسماعيل بن عمر بن كثير القريثي ابو الفداء - ج 1 ص ص 280 - البد/بية والعه/ية ، مكتبة المعارف ـ

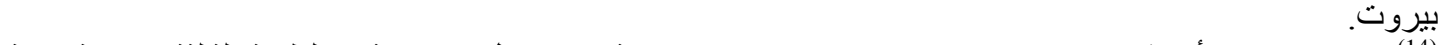
القاهرة: بكير بن سعيد أعوشت : 1988م ، ص :14- دراسات الاسلامية في اصول الاباضية ، الطبعة الثالثة ـ مكتبة وهبةـ عيداله الهصدر نفسه : ج 8 - ص ص 239. ابن الأثير، 1415، ابو الحسن علي بن ابي الكرم المشهور بابن أثثر: تحقيق :

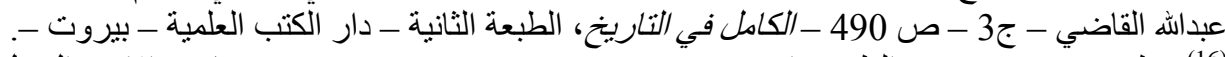

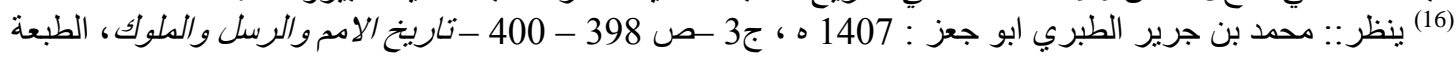

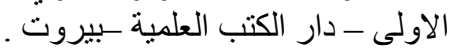

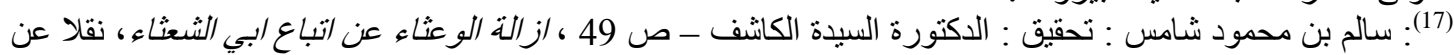

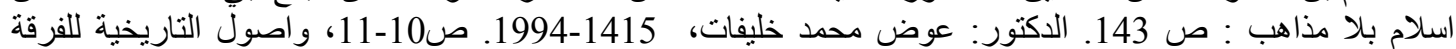

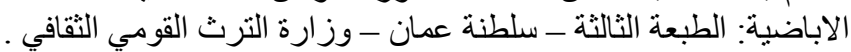




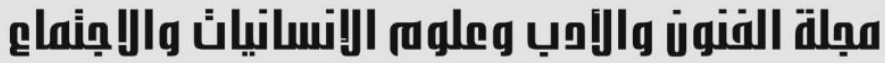

www.jalhss.com

(20): محمد بن اسماعيل : ابو عبداله البخاري: تحقيق: السيد هاشم الندوي: ج1 جـ ص204 ص205 ، التاريخ الكبير - دار الفكر.

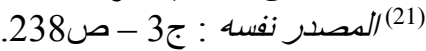

(22): احمد بن علي بن حجر ابو الفضل العسقلاني: 1984م ، ج2- صـ34- تهزيب التهزيب، الطبعة الاولىـ دار الفكر -

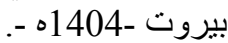

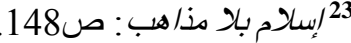

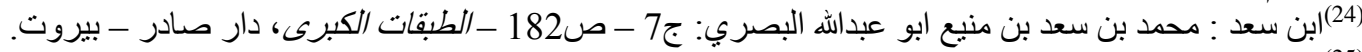

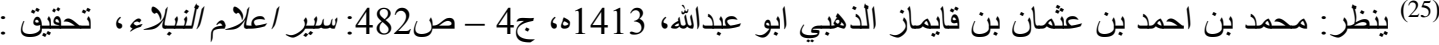

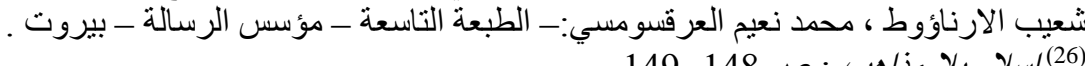

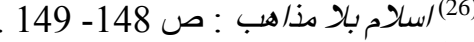

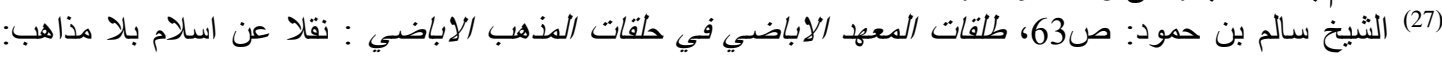

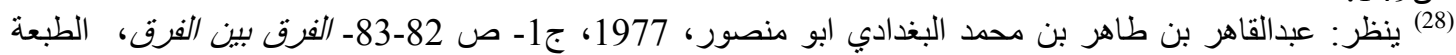

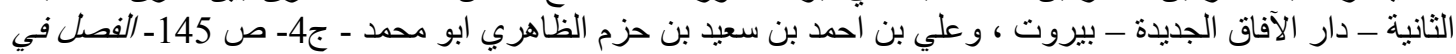

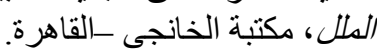
$204:$ : (29) 207 : (30)

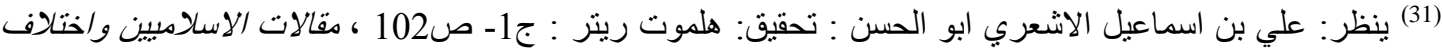

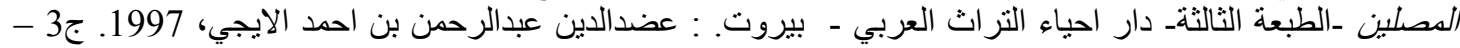

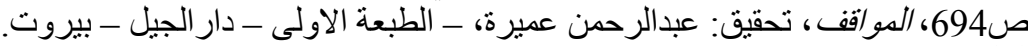

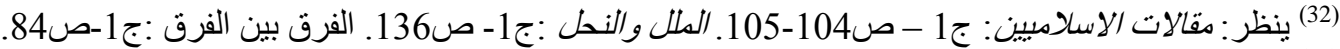

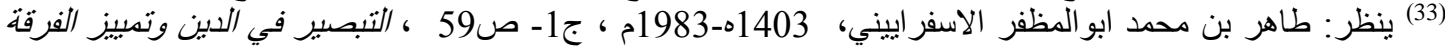

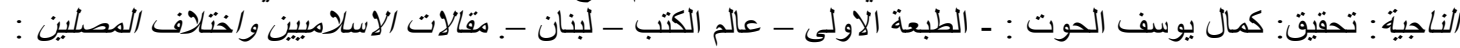

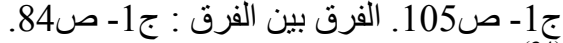

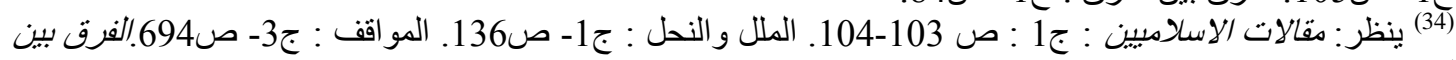

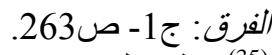

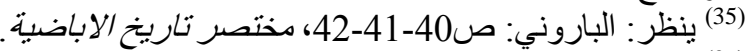

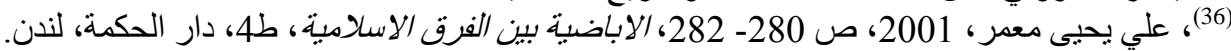

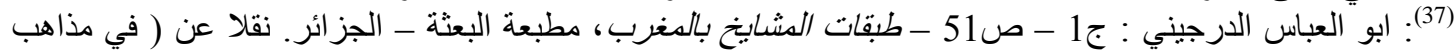

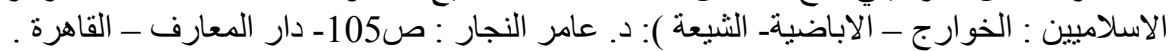

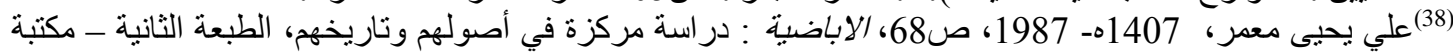

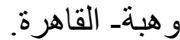

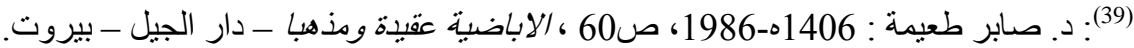
(40) الباروني : ص 45 45، مختصر تاريخ الاباضية.

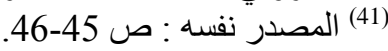

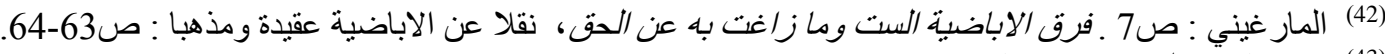

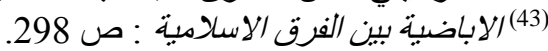

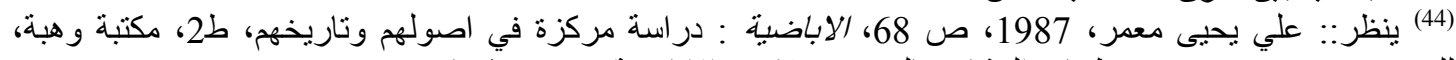

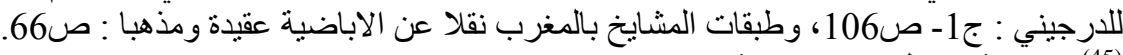

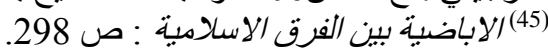

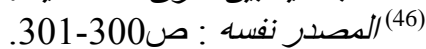

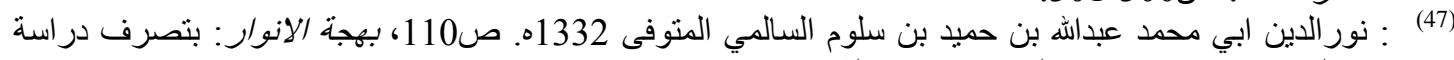

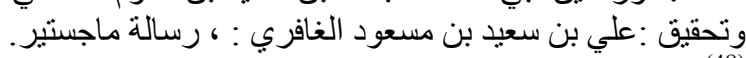
11 : (48)

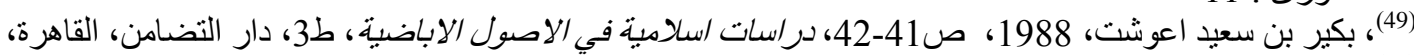

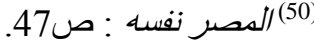




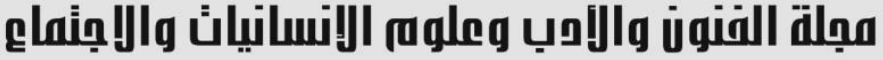

Journal of Arts, Literature, Humanities and Social Sciences www.jalhss.com

(51): ناصر بن سالم الرواحي: 1400ه، 1- صل 21- نثائر الجوهر في علم الثرع الازهر الطبعة الاولى - مسقط سلطنة عمان. (52): سالم بن حمود : صلن :99، طلقات الدعهُ الاباضي، نقلاعن رسالة ماجستير: التأويل الكلامي عندالاباضية: عبداله بن

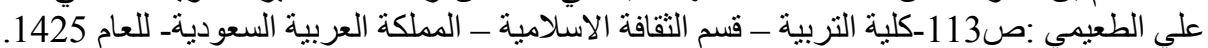

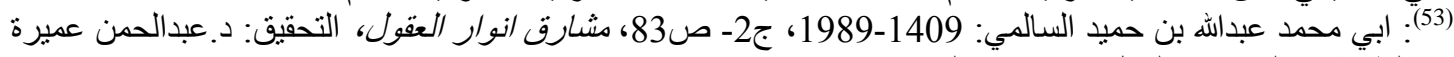

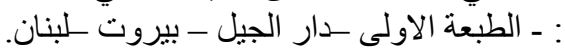
. (54)

(55) ينظر: د. يحة : بحيى هويدي: 1979، ص1134، دراسات في علم الكلام والفلسفة الاسلامبية ، الطبعة الثانية، دار الثقافة:القاهيرة. (56) ينظر : بكير: صاهرة: ص202-53، دراسات / سلامية في اصول الاباضية.

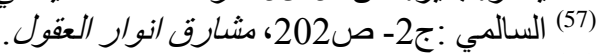
109-108 : النحل : (58) 14 : 14 : (59)

3-1 : (60) (60) العنكبوت : (59)

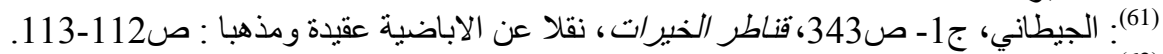

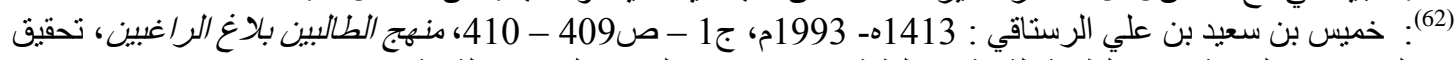

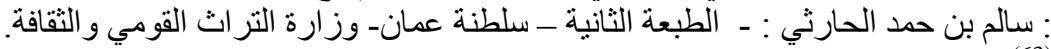
23-22 : (63) القيامة : 103 : 103 : الانعام: (65)

(65) ينظر : بكير: 58-58 الانعام 103، دراسات الاسلامبية في الاصول الاباضية.

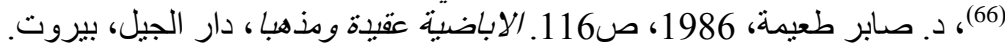

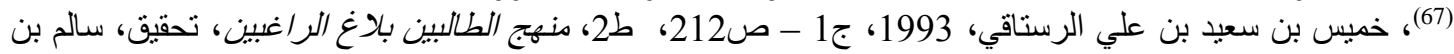

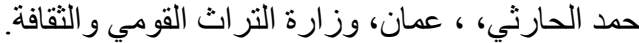
(68) (68) الفرقان : الارني، (69) (60) الانبياء: (68)

(70): سالم بن حمود : صل 270 27 ، الحقبقة والمجاز وما بعدها : نقلا عن التأويل الكلامي عند الاباضية : ص120 ـ. 23: (71) (72) (72) البقرة: 81.

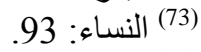
16-13 : 17) الانفطار: (74) (75)،السالمي ابو محمد 13-16، عبدارله بن حميد، 1989، ج2 - ص144-145، مشارق /نوار العقول، تحقيق: د. عبدالرحمن

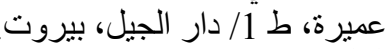

(76): د. يحيى هويدي، دارئ 1979، ص 19 119، ط2، دراسات في علم الكلام والفلسفة الاسلامبية ، دار الثقافة، القاهرة.

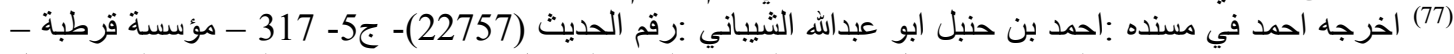
مصر-عدد الاجز اء : 6. وهذا ليس كلام رسول الله ( صلى الله عليه وسلم ) بل من كلام عبادة بن الصامت قاله لابنه قبل

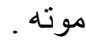

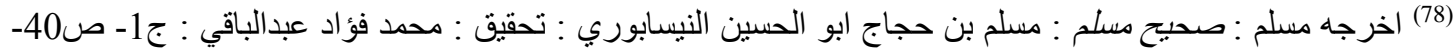

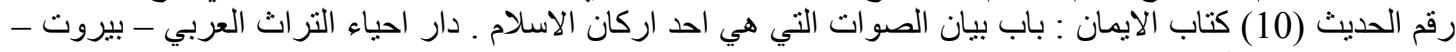

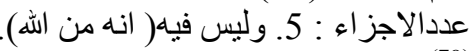
(79) (79) البقرة: 286. (280)

43 : (80)

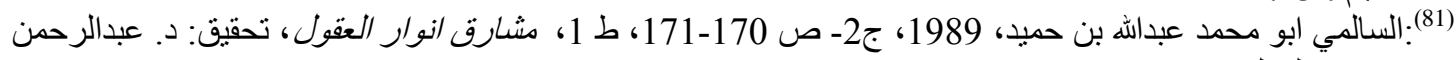

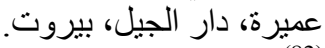

(82)، بكير بن سعيد اعوشت، ارون، 1988، ص 80، دراسات الاسلامية في اصول الاباضية، ط3، دار التضامن، القاهرة.

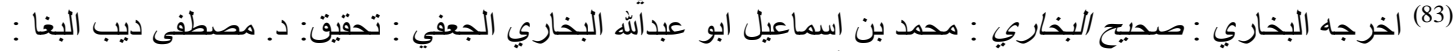

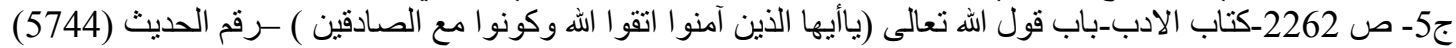

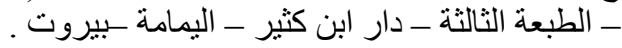




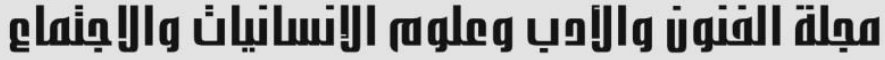

Journal of Arts, Literature, Humanities and Social Sciences www.jalhss.com

\section{المصادر والمراجع}

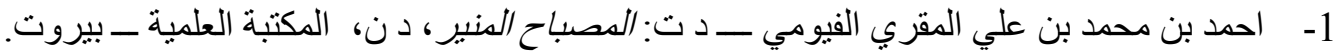

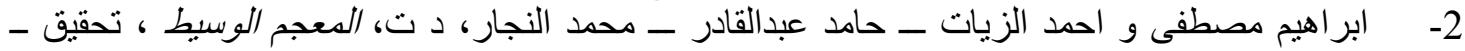

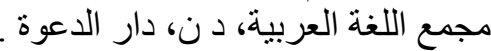

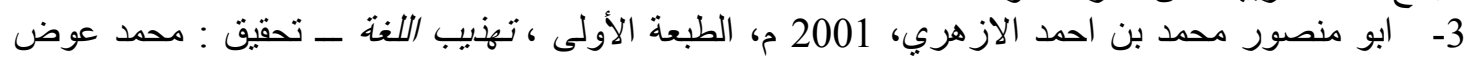

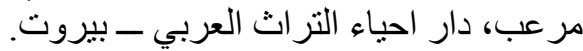

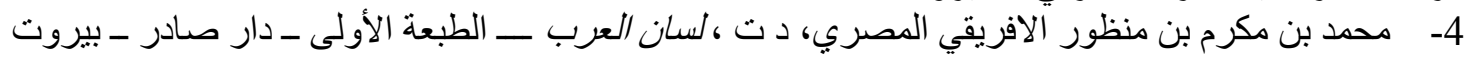

5- محد مرتضى الحسيني الزبيدي، د ت ، تاج العروس من جواهر القاموس، تحقيق : مجموعة من المحققين، دار الهداية.

6- الثهرستاني: محمد بن عبدالكريم بن ابي بكر احمد الثهرستاني المتوفى 458 هـ ـ تحقيق : محمد سيد

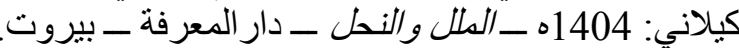
7- الاشعري: علي بن اسماعيل الاشعري ابو حسن المتوفى 324 هـ ــ تحقيق : هلموت ريتر: مقالات

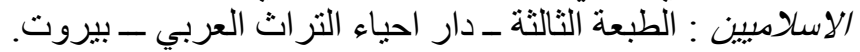

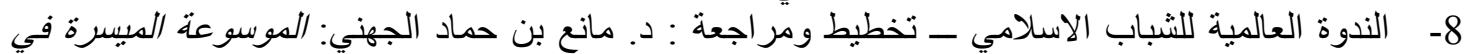

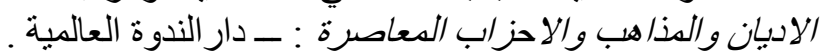

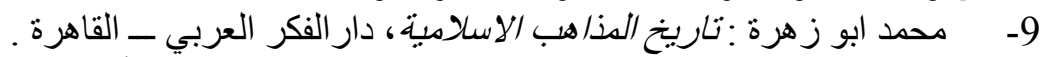

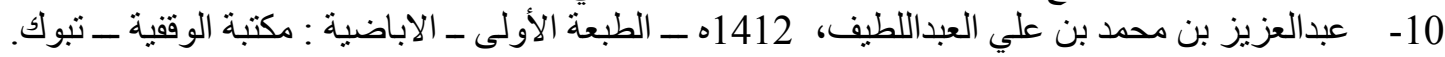

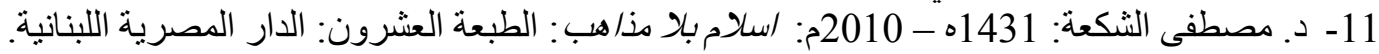

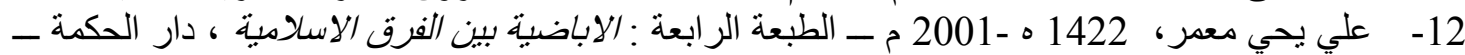

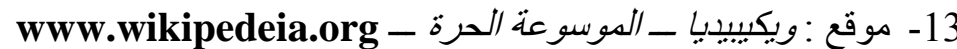

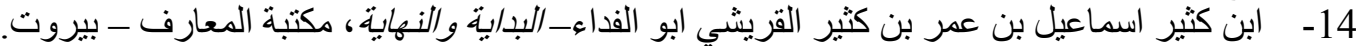

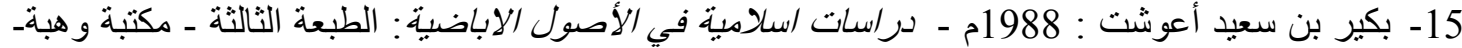

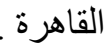
16- ابو الحسن علي بن ابي الكرم المشهور بابن أثثير: 1415ه: تحقيق: عبداله القاضي- الكامل في التاريخ،

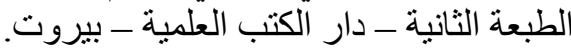
17- محمد بن جرير الطبري ابو جعفر : 1407 ه: تاريخ الامم والرسل والملوك، الطبعة الاولى ـ دار الكتب

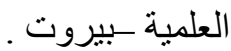

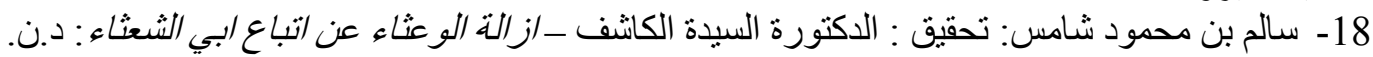
19- الدكتور: عوض محمد خليفات، 1415ه-1994م: اصول التاريخية للفرقة الاباضية: الطبعة الثالثة ـ سلطنة عمان - وزارة الترث القور القومي الثقافي .

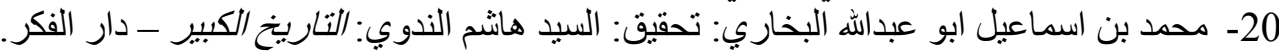
21- احمد بن علي بن حجر ابو الفضل العسقلاني: 1404هـ 1984م: تهذيب التنهذيب، الطبعة الاولىــ دار الفكر 


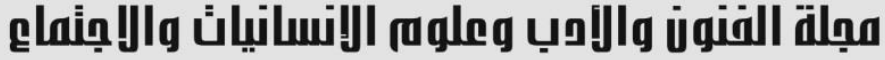
www.jalhss.com

22- ابن سعد: محمد بن سعد بن منيع ابو عبدالله البصري: الطبقات الكبرى، دار صادر - بيروت.

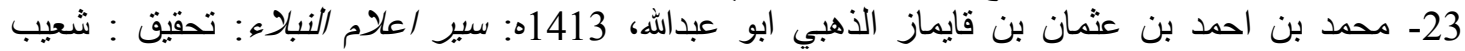

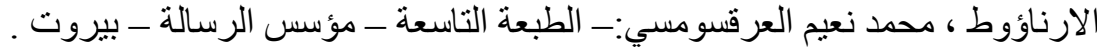

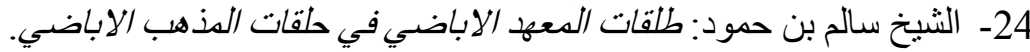

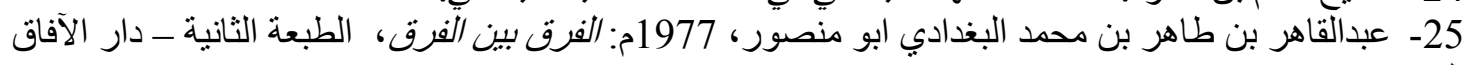

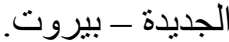

26- علي بن احمد بن سعيد بن حزم الظاهري ابو محمد : الفصل في الملال، مكتبة الخانجي ـالقاهرة.

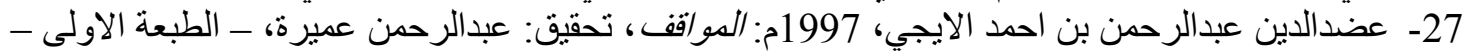

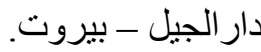
28- طاهر بن محمد ابو المظفر الاسفراييني: 1403ه-1983م: التبصير في الدين وتمبيز الفرقة الناجية: تحقيق: كمال يوسف الحوت: الطبعة الاولى:عالم الكتب - لبنان البنان. 29- ابو العباس الدرجيني :طبقات المشايخ بالمغرب : مطبعة البعثة ــ الجزائر.

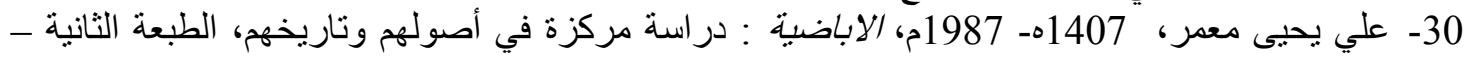
مكتبة و هبة القاهرة 31- د. صابر طعيمة : 1406ه-1986م ، الاباضية عقيلة ومذهبا - دار الجيل - بيروت.

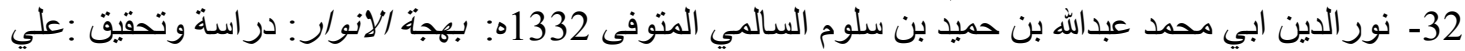
بن سعيد بن مسعود الغافري : رسالة ماجستير. 33- ناصر بن سالم الرواحي: 1400ه ـ نثائر الجوهر في علم الثرع الازهر الطبعة الاولى - مسقط - سلطنة عمان. 34- التأويل الكلامي عندالاباضية: 1425ه: عبدالله بن علي الطعيمي: ـكلية التربية ـ قسم الثقافة الاسلامية ـ المملكة العربية السعودية. 35- ابو محمد عبداله بن حميد السالمي: 1409ه-1989م: مشارق انوار العقول، التحقيق: د.عبدالحمن عميرة :

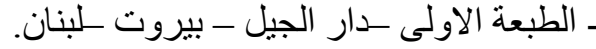

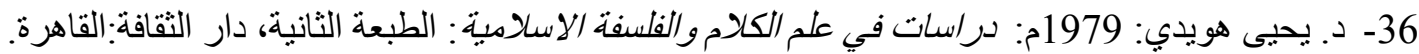

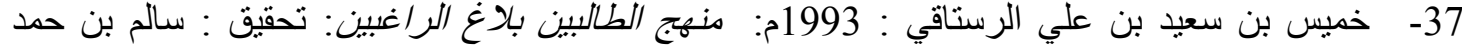

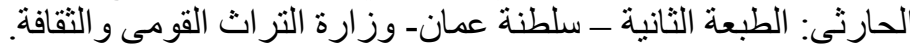

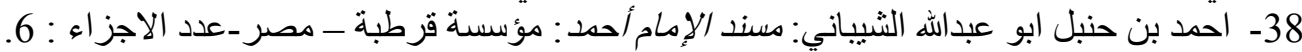
39- مسلم بن حجاج ابو الحسين النيسابوري: صحيح مسلم : تحقيق : محمد فؤاد عبدالباقي : دار احياء التئ التراث

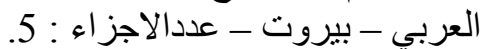
40- " محمد بن اسماعيل ابو عبدالله البخاري الجعفي: صحيح البخاري : تحقيق: د. مصطفى ديب البغا : الطبعة

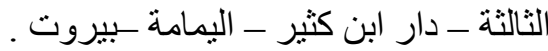
41- د. غالب بن علي عواجي، 1422هـ-2001م: فرق الئ اسلامية تنتسب الى الاسلام وبيان موقف الاسلام منها،

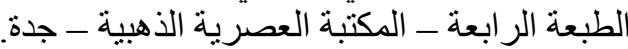
42- علي يحيى معمر: 1414هـ 1993م: الاباضية في موكب التاريخ ، الطبعة الثنانية: مكتبة وهبة ـ القاهرة. 


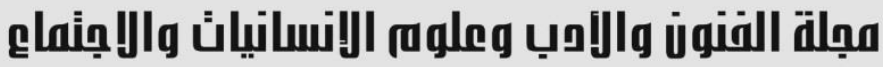

\section{References}

1. Ahmed bin Muhammad bin Ali al-Muqri al-Fayoumi - N.D .: Al-Misbah al-Munir, dn, Scientific Library - Beirut.

2. Ibrahim Mustafa and Ahmed al-Zayyat - Hamed Abdel-Qader - Muhammad alNajjar, D.T., The Intermediate Dictionary, Investigation - The Arabic Language Academy, Dar Al-Dawa.

3. Abu Mansour Muhammad bin Ahmad Al-Azhari, 2001, first edition, Refining the Language - Achievement: Muhammad Awad Marab, Arab Heritage Revival House Beirut.

4. Muhammad bin Makram bin Perspective of the African-Egyptian, N.D., Lisan AlArab - First Edition - Dar Sader - Beirut.

5. Muhammad Murtadha al-Husseini al-Zubaidi, N.D., The Crown of the Bride, Jewels of the Dictionary, Investigation: A Group of Investigators, Dar al-Hidaya.

6. Al-Shahristani: Muhammad ibn Abd al-Karim ibn Abi Bakr Ahmad al-Shahristani, who died 458 AH - investigation: Muhammad Sayyid Kilani: 1404 AH - boredom and bees - Dar al-Maarifa - Beirut.

7. Al-Ashari: Ali bin Ismail Al-Ashari Al-Ashari Abu Hassan, died 324 AH. Achievement: Helmut Ritter: Islamists' Articles: Third Edition - Dar Al-Ahyaa AlArabi Heritage - Beirut.

8. The World Assembly of Muslim Youth - Planning and Review: Dr. Manea Bin Hammad Al-Juhani: The Facilitated Encyclopedia of Religions, Doctrines, and Contemporary Parties: The International Colloquium.

9. Muhammad Abu Zahra: A History of Islamic Schools of Thought, Arab Thought Center - Cairo.

10. Abdulaziz bin Muhammad bin Ali Al-Abdullatif, 1412 AH - First Edition Al-Ibadiya: Al-Waqfiya Library - Tabuk.

11. Dr.. Mustafa Al-Shaka'a: 1431 AH - 2010 AD: Islam without doctrines: The twentieth edition: The Egyptian Lebanese House.

12. Ali Yahya Muammar, 1422 AH-2001 CE - Fourth Edition: The Ibadhi among the Islamic Sects, Dar Al-Hikma - London.

13. Website: Wikipedia - the free encyclopedia - www.wikipedeia.org

14. Ibn Katheer Ismail bin Omar bin Katheer al-Quraishi Abu al-Fida - Beginning and End, Al-Maaref Library - Beirut.

15. Bakir bin Saeed Aawasht: 1988 AD - Islamic studies in the principles of Ibadi: the third edition - Wahba Library - Cairo.

16. Abu al-Hasan Ali bin Abi al-Karam, famous for Ibn Athir: 1415 AH: Investigation: Abdullah al-Qadi - The Complete History, Second Edition - Dar alKutub al-Alami - Beirut.

17. Muhammad bin Jarir al-Tabari Abu Ja'far: 1407 AH: History of the Nations, Messengers and Kings, first edition - Dar al-Kitab al-Alami - Beirut. 


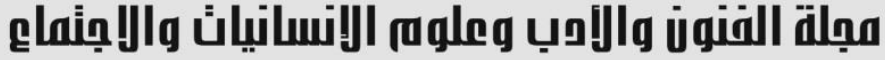 \\ Journal of Arts, Literature, Humanities and Social Sciences www.jalhss.com \\ Volume (53) June 2020 \\ العدد (53) يونيو 2020}

18. Salem bin Mahmoud Shams: Investigation: Dr. Al-Sayed Al-Kashef Removal of Moth for Abi Al-Shaathaa.

19. Dr.: Awad Muhammad Khleifat, 1415 AH-1994 AD: The Historical Origins of the Ibadi Ensemble: Third Edition - Sultanate of Oman - Ministry of National Cultural Heritage.

20. Muhammad bin Ismail Abu Abdullah Al-Bukhari: Investigation: Mr. Hashem Al-Nadawi: The Great History - Dar Al-Fikr.

21. Ahmad bin Ali bin Hajar Abu al-Fadl al-Asqalani: 1404 AH - 1984 AD: Refining Discipline, First Edition - Dar al-Fikr - Beirut.

22. Ibn Sa`d: Muhammad ibn Sa`d ibn Mu``ya Abu Abdullah al-Basri: The Great Classes, Dar Sader - Beirut.

23. Muhammad bin Ahmad bin Othman bin Qaymaz al-Thahabi Abu Abdullah, 1413 AH: Biographies of the Nobles' Media: Investigation: Shoaib Al-Arnaout, Muhammad Naim Al-Arksomsi: - The ninth edition - The founder of the message Beirut.

24. Sheikh Salem bin Hamoud: The shots of the obscene institute in the episodes of the obscene sect.

25. Abdel-Qaher bin Tahir bin Muhammad al-Baghdadi Abu Mansour, 1977 AD: The Difference between Teams, Second Edition - Dar al-Afaq al-Jadida - Beirut.

26. Ali bin Ahmed bin Saeed bin Hazm Al-Dhaheri Abu Muhammad: Chapter in Boredom, Al-Khanji Library - Cairo.

27. Adad al-Din Abd al-Rahman ibn Ahmad al-Eiji, 1997: Attitudes: Achievement: Abd al-Rahman Amira, - First Edition - Dar al-Jeel - Beirut.

28. Taher Bin Muhammad Abu Al-Mudhafar Al-Asfaraeeni: 1403 AH -1983 AD: Insight into Religion and Distinguishing the Survivor Division: Achievement: Kamal Yusef Al-Hout: First Edition: World of Books - Lebanon.

29. Abu al-Abbas al-Darjini: The layers of sheikhs in Morocco: the Mission Press - Algeria.

30. Ali Yahya Muammar, 1407 AH - 1987 AD, Al-Ibadi: a focused study on their origins and history, second edition - Wahba Library - Cairo.

31. Dr.. Saber To'eima: 1406 AH -1986 CE, the Ibadi Creed and Doctrine - Dar Al-Jeel - Beirut.

32. Nour al-Din Abi Muhammad Abdullah bin Hamid bin Saloom al-Salmi (d. 1332 AH): The Joy of Lights: A study and investigation: Ali bin Saeed bin Masoud al-Ghafiri: Master Thesis.

33. Nasser bin Salem Al-Rawahi: $1400 \mathrm{AH}$ - Prospects of the Essence in Al-Azhar Sharia Science, First Edition - Muscat - Sultanate of Oman.

34. Verbal interpretation of Al-Abadi: 1425 AH: Abdullah bin Ali Al-Tuaimi: College of Education - Department of Islamic Culture - Saudi Arabia.

35. Abu Muhammad Abdullah bin Humaid Al-Salmi: 1409 AH -1989 AD: Mashreq Anwar Al-Aqoul, Investigation: Dr. Abdullah Omaira: - First Edition - Dar Al-Jeel - Beirut - Lebanon. 


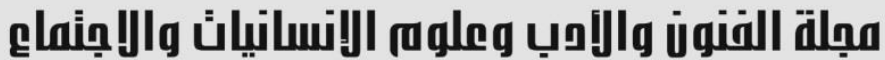

36. Dr. Yahya Huwaidi: 1979 AD: Studies in Islamic theology and philosophy: second edition, Dar al-Thaqafa: Cairo.

37. Khamis bin Saeed bin Ali Al-Rustaqi: 1993 AD: the curriculum of students requesting a communication of those who wish: an investigation: Salem bin Hamad Al-Harthi: Second Edition - Sultanate of Oman - Ministry of National Heritage and Culture.

38. Ahmad ibn Hanbal Abu Abdullah al-Shaibani: Imam Ahmad Imam: Qurtoba Foundation - Egypt - Number of parts: 6.

39. Muslim bin Hajjaj Abu Al-Hussein Al-Nisaburi: Sahih Muslim: Investigation: Muhammad Fouad Abdel Baqi: House of Arab Heritage Revival - Beirut - Number of parts: 5 .

40. Muhammad bin Ismail Abu Abdullah Al-Bukhari Al-Jaafi: Sahih Al-Bukhari: Investigation: Dr. Mustafa Deeb Al-Bagha: Third Edition - Dar Ibn Katheer - AlYamamah - Beirut.

41. Dr.. Ghaleb bin Ali Awaji, 1422 AH -2001 AD: Islamic groups affiliated with Islam and the statement of Islam's position thereon, fourth edition - The Modern Golden Library - Jeddah.

42. Ali Yahya Muammar: 1414 AH - 1993 AD: The Ibadite in the Procession of History, Second Edition: Wahba Library - Cairo 